\title{
In-Vivo Toxicity Assessment of Stem Bark Extracts of Spondias mombin (Linn) on Male and Female Albino Rats
}

\section{Osuntokun $\mathrm{OT}^{1 *}$ and Oluduro $\mathrm{AO}^{2}$}

${ }^{1}$ Department of Microbiology, Adekunle Ajasin University, Nigeria

${ }^{2}$ Department of Microbiology, Obafemi Awolowo University, Nigeria

*Corresponding author: Osuntokun OT, Department of Microbiology, Faculty of

\section{Research Article}

Volume 2 Issue 1

Received Date: March 30, 2018

Published Date: April 16, 2018

Science, Adekunle Ajasin University, Akungba Akoko, P.M.B 001, Ondo State, Nigeria, Tel: 08063813635/ 08056096672;

Email: osuntokun4m@gmail.com

\section{Abstract}

Spondias mombin is depends on for various herbal remedies for the treatment of numerous health conditions. This study is to evaluate the In-vivo toxic effect of Stem bark extracts of Spondias mombin on in male and female albino rats. In-vivo toxicity test was carried out with modified Lorke's method. Forty two (42) male and female albino rats weighing between $120-180 \mathrm{~g}$ were used for the sub-chronic study. The rats were divided into five groups A- $\mathrm{D}(\mathrm{n}=12)$. The albino rats were divided into four groups labelled A, B, C, and D with group A, B, and C consisting of 12 rats each, while the remaining 6 rats served as control which were placed in group D. Group A, B and C were fed with $200 \mathrm{mg} / \mathrm{kg}$ and $500 \mathrm{mg} / \mathrm{kg}$ body weight doses of crude aqueous, ethanol and ethyl acetate stem bark extracts of S.mombin, respectively with the aid of an oral gastric tube. Treatments lasted for twenty one days (21). Acute toxicity test carried out showed that stem bark extracts of $S$. mom bin did not produce mortality in rats. Significant $(\mathrm{p}<0.05)$ reduction in brain and kidney weights was observed in group C treated with $200 \mathrm{mg} / \mathrm{kg}$ and $500 \mathrm{mgkg}-1$ of crude ethyl acetate stem bark extracts of S. mombin. Similarly, significant $(\mathrm{p}<0.05)$ reduction was observed in spleen weights in groups $C$ and $D$ that were treated with 200 $\mathrm{mg} / \mathrm{kg}$ and $500 \mathrm{mgkg}-1$ of both extracts. The levels of LDL $(\mathrm{p}<0.001)$ and ALP $(\mathrm{p}<0.05)$ were significantly reduced. It can be concluded that, this result suggests that, the use of the stem bark extracts of S.mombin is relatively safe.

Keywords: Medical scans; Computed tomography; X-ray; Imaging; Denoise; Fusion 


\section{Open Access Journal of Pharmaceutical Research}

Abbrevations: SLT: Science and Laboratory Technology; ROW: Relative Organ Weight; ALT: Alanine Amino Transferase; AST: Aspartate Amino Transferase; ALP: Alkaline Phosphatase.

\section{Introduction}

More than $80 \%$ of the world's population need, to prevent and treat their diseases depends upon traditional medicine, therefore, attention to the use of medicinal plants is being widespread and plants still represent the largest source of natural antioxidants and antimicrobial components [1]. Research on plants with medicinal properties and identification of the chemical components responsible for their activities have justified the ancient traditional healing wisdom and have proven the enduring healing potential of many plant medicines [2]. Wild plants have always been a major source for primary health care and other necessities of daily life for local communities throughout the world, an indication that medicinal plants can provide the best alternative source to obtain a variety of drugs. Drugs of natural origin now play an ever more important role in medical and healthcare services because metabolites produced by plants constitute a major source of bioactive substances which can be used as an alternative for cheap and effective herbal drugs against common infections [3].

Spondias mombin belongs to the family Anacardiaceae. It is native to the tropical America and has been naturalized in parts of Africa, India and Indonesia and it is one of the medicinal herbs in Southern Nigeria. It is called hog plum in English, akika in Yoruba, ijikara in Igbo, tsardarmaser in Hausa and chabbuh in Fulani and nsukakara in Efik [4]. The plant has been traditionally noted for its medicinal and food values. Preliminary results report a wide range of antibacterial and antifungal properties [5].

The fruit juice is drunk as a diuretic and febrifuge. The decoction of the astringent bark serves as an emetic, a remedy for diarrhaea, dysentery, haemorrhoids and a treatment for gonorrhoea and leukorrhea. In Mexico, it is believed to expel calcifications from the bladder. A tea made from the flowers and leaves is taken to relieve stomach ache, biliousness, urethritis, cystitis and eye and throat inflammations [6]. The juice of crushed leaves and the powder of dried leaves are used as poultices on wounds and inflammations [7]. The gum is employed as an expectorant and to expel tapeworms [8-11]. Concerning the popular use of this plant, the leaves were mentioned in the literature as abortifacient, antimicrobial, anti-viral, Vitamin C, Wound-healer [12-15,7].

\section{Materials and Methods}

\section{Test Animals}

Forty two (42) adult male and female albino rats with an average weight of $120 \mathrm{~g}-180 \mathrm{~g}$, ages 3 to 4 weeks old were used for this study. The rats were obtained from the Department of Biochemistry, Federal University of Technology Akure, Ondo while some were obtained from Science and Laboratory Technology (S.L.T.) Federal Polytechnic Ado-Ekiti. The study was carried out according to the recommended standard for laboratory animal use, while the rats were fed with commercial rat chow obtained from Pfizer Nigeria Ltd, Lagos State, Nigeria and distilled water.

\section{Experimental Cage}

The observation cage was used $(30 \mathrm{~cm}$ by $30 \mathrm{~cm}$ by 25 $\mathrm{cm}$ ) with an open surface for maximal ventilation and illumination. It was constructed, such that 9 rooms were observed in three story steps cage i.e. 3 rooms at each steps for the rats' comfort with $5 \mathrm{~cm}$ stand of the cage to stand firm on the ground, and also to prevent penetration of insect from entering the cage.

\section{Toxicological Assay of Spondias mombin on Experimental Animal}

In-vivo toxicity test was carried out and median lethal dose was calculated using modified method of Lorke [16]. Forty two (42) male and female albino rats were used for this research work. The albino rats were divided into four groups labeled A, B, C, and D with group A, B, and C consisting of 12 rats each, while the remaining 6 rats served as control which were placed in group D. Group A, $\mathrm{B}$ and $\mathrm{C}$ were fed with $200 \mathrm{mg} / \mathrm{kg}$ and $500 \mathrm{mg} / \mathrm{kg}$ body weight doses of crude aqueous, crude ethanolic and crude ethyl acetate stem bark extracts of Spondias mombin, respectively with the aid of an oral gastric tube. The albino rats were acclimatized to the experimental condition at room temperature by administering daily ration of food without Spondias mombin extracts for fourteen (14) days, after which, various concentrations of various extracts of Spondiasmonbin were administrated to each group of the albino rat for 21 days. Then food consumption and water intake of the groups were measured daily. Body weights of all rats in the groups were recorded weekly [17]. 


\section{Open Access Journal of Pharmaceutical Research}

Four (4) albino rats each from groups A, B and C and that of control group D were anaesthetized using chloroform inhalation for 24 hours, and blood was drawn from the heart by cardiac puncture using a needle gauge and syringe. A portion was transferred immediately into EDTA-containing tubes and plane tubes for measurement of heamatological parameters and serum biochemical analysis. The blood was centrifuged at 10,000 rpm for 5 minutes, and serum analyzed as described by Abad et al. [18]. The same procedure as described above was carried out on another sets of albino rats with the control on the fourteen and twenty one days of extract administration, respectively.

\section{Histo-Pathological Test}

Preparation of Organ Homogenate: The liver, heart, lungs, kidneys, stomach, spleen, gonads and brain were excised after sacrificing the albino rats using sterilized dissecting kits and surgical blades. These were weighed on a beam balance and Relative Organ Weight (ROW) was calculated by expressing absolute organ weight as a percentage of the total body weight. The liver and kidneys were fixed in $10 \%$ buffered formalin for 48 hours for routine histology using Haematoxylin and Eosin staining method. The slides were examined using the light microscope for any morphological changes. The homogenate was centrifuged at $3000 \mathrm{rpm}$ for $10 \mathrm{~min}$. using Bench centrifuge. The supernatant was carefully collected into clean vial bottle and stored in freezer for further biochemical assays. Results were expressed as Mean \pm SD. Statistical analysis was carried out by one-way ANOVA. Data were further subjected to post hoc test and differences between treated groups and control were taken as significant at $\mathrm{p}<0.01$ and $\mathrm{p}<0.05$ [19].

Hematological Analysis: Blood samples were collected by cardiac puncture into two sets of plain and EDTAtreated sample bottles. The hematological parameters and enzymes assay were carried out respectively. The blood in the plain sample bottles were allowed to clot, after 3 hours. The clotted blood samples were spun in a bench top centrifuge (MSE, England) to obtain sera.

Preparation of Blood Plasma: The serum samples were separated into another set of plain sample tubes. The separated serum samples were stored in the refrigerator until required for the enzyme analyses. The whole blood collected into EDTA-treated sample bottles were used for hematological indices. All assays were done within 24 hours of the sample collection [20]. The hematocrit or packed cell volume was determined according to the hematocrit method, while the hemoglobin concentrations were determined by cyano-methaemoglobin method, described by Alexander, et al. [20]. The red blood cell counts were estimated by the visual method described by Dacie, et al. [21].

Assay of Serum Enzymes and Renal Function Markers: The serum enzymes, alanine amino transferase (ALT), aspartate amino transferase (AST), alkaline phosphatase (ALP), total protein, albumin and urea assays were carried out using enzymes kits by Randox Laboratories Ltd, United Kingdom. The blood samples in the EDTA tubes were centrifuged for 15 minutes at $40 \mathrm{C}$ and analyzed according to the manufacturer description.

\section{Biochemical Assays}

The following biochemical assays were carried out to evaluate the safety or toxicity risk of stem bark extract of S.mombin,

Determination of Alanine Aminotransferase (ALT) Activity Serum of Experimental Animal: The plasma and liver alanine aminotransferase activities were estimated according to the method of Dacie, et al. [21], using Randox Diagnostic Kit (Randox Laboratories Ltd, Antrim, UK). The kit contained two reagents bottles; reagent one (R1) consisted phosphate buffer (100 $\mathrm{mmol} / \mathrm{L}, \mathrm{pH}$ 7.4), $200 \mathrm{mmol} / \mathrm{L} \mathrm{L}$-aspartate and $2 \mathrm{mmol} / \mathrm{L}$ $\alpha$-oxoglutarate while reagent two (R2) contained 2, 4dinitrophenyl hydrazine $(2.0 \mathrm{mmol} / \mathrm{L})$.

Principle: ALT catalyses the transfer of amino group between L-alanine and $\alpha$-ketoglutarate to form pyruvate and glutamate. Alanine aminotransferase activity is measured by monitoring the concentration of pyruvate hydrazone formed with 2, 4-dinitrophenylhydrazine.

\section{+L-Glutamate}

Alanine $+\alpha$-Ketoglutarate $(\rightarrow \perp$ ALT $)$ Pyruvate

Procedure: The plasma $(0.1 \mathrm{ml})$ was pipetted separately into clean test tubes in triplicates and $0.5 \mathrm{ml}$ of the buffer was added and mixed gently. The reaction mixture was incubated at $37^{\circ} \mathrm{C}$ for $30 \mathrm{~min}$ in a water bath. The reaction mixture was cooled and $0.5 \mathrm{ml}$ of 2, 4dinitrophenlhydrazine $(2.0 \mathrm{mM})$ was added. The mixture was mixed properly and allowed to stand at room temperature for additional $20 \mathrm{~min}$, after which $5 \mathrm{ml}$ of 0.4 $\mathrm{M} \mathrm{NaOH}$ solution was added and mixed properly. The absorbance of the reaction mixture was taken at $546 \mathrm{~nm}$ against a reagent blank prepared with distilled water $(0.1$ $\mathrm{ml}$ ) in place of the sample. 


\section{Open Access Journal of Pharmaceutical Research}

Estimation of Aspartate Aminotransferase (AST) Activity in the Serum of Experimental Animal: Alanine aminotransferase activity was estimated according to the method Dacie et al. [21], using Randox Diagnostic Kit. The kit contained two reagents bottles; reagent one (R1) consisted of $100 \mathrm{mmol} / \mathrm{L}$ phosphate buffer, pH 7.4; 100 $\mathrm{mmol} / \mathrm{L} \mathrm{L}$-aspartate and $2.0 \mathrm{mmol} / \mathrm{L} \alpha$-oxoglutarate while reagent two (R2) contained 2, 4- dinitrophenyl hydrazine $(2.0 \mathrm{mmol} / \mathrm{L})$.

Principle: AST catalyzes the transfer of amino group between $L$-aspartate and $\alpha$-ketoglutarate to form oxaloacetate and glutamate. Aspartate aminotransferase activity is measured by monitoring the concentration of oxaloacetate hydrazone formed with 2, 4dinitrophenylhydrazine.

Aspartate $+\alpha$-Ketoglutarate $\square(\rightarrow \perp$ AST $)$ Oxaloacetate $+\mathrm{L}$ Glutamate

Determination of Urea Concentration in the Serum of Experimental Animal: Urea was hydrolyzed by urease enzyme to yield ammonia and carbon (IV) oxide; the liberated ammonia reacted with phenol in an acid medium (hypochlorite) to produce indophenols; a blue colored compound solution was read at $546 \mathrm{~nm}$ using spectrophotometer. To $10 \mu \mathrm{l}$ of sample was added $100 \mu \mathrm{l}$ of urease reagent I, followed by $2.5 \mathrm{ml}$ each of urease reagents II and III and was incubated for 25 minutes at $370 \mathrm{C}$ and read at $546 \mathrm{~nm}$ [7].

Determination of Total Protein in the Serum: The total protein test kit (Randox Diagnostic Laboratories, Ltd) was used for the estimation of the plasma total protein according to the biuret reaction method, as reported by Ayoka [7]. The kit contained biuret reagent $(100 \mathrm{mmol} / \mathrm{L}$ $\mathrm{NaOH}, 16 \mathrm{mmol} / \mathrm{L} \mathrm{Na-K-tartarate,} 15 \mathrm{mmol} / \mathrm{L}$ Potassium iodide and $6 \mathrm{mmol} / \mathrm{L}$ Cupric sulphate) and a blank reagent consisted of $(100 \mathrm{mmol} / \mathrm{L} \mathrm{NaOH}$ and $16 \mathrm{mmol} / \mathrm{L}$ Na-K-tartarate).

Principle: Proteins, in alkaline medium, bind with the cupric ions present in the biuret reagent to form a blueviolet coloured complex. The intensity of the colour formed was directly proportional to the amount of proteins present in the sample.

Protein $+\mathrm{Cu}^{\wedge}(++) \rightarrow$ Blue Violet Coloured Complex

Procedure: The plasma $(0.01 \mathrm{ml})$ was separately pipetted into clean test tubes in triplicates and $0.5 \mathrm{ml}$ biuret reagent was added and mixed thoroughly. The standard contained $0.01 \mathrm{ml}$ biuret reagent and $0.5 \mathrm{ml}$ standard solution (Bovine Serum Albumin). Each of the mixtures was incubated for $30 \mathrm{~min}$. at $25^{\circ} \mathrm{C}$. The absorbance of the sample and standard were measured at $546 \mathrm{~nm}$ against a sample blank prepared with distilled water $(0.01 \mathrm{ml})$ in place of sample. The total protein concentration was estimated from the expression below;

Total protein concentration (g/dL)

$$
\begin{aligned}
& =\frac{\mathrm{Abs}_{\text {sample }}}{\mathrm{Abs}_{\text {standard }}} \mathrm{X} \text { Standard concentration (g } \\
& / \mathrm{dL})
\end{aligned}
$$

Estimation of Total Bilirubin Concentration: Plasma total bilirubin concentration was estimated colorimetrically according to the method of using Randox Diagnostic Kit. The kit contained four different reagents; reagent one $(29 \mathrm{mmol} / \mathrm{L}$ Sulphanilic acid and $0.17 \mathrm{~N} \mathrm{HCl})$, reagent two (38.5 mmol/L Sodium Nitrite), reagent three ( $0.26 \mathrm{~mol} / \mathrm{L}$ Caffeine and $0.52 \mathrm{~mol} / \mathrm{L}$ Sodium benzoate) and reagent four $(0.93 \mathrm{~mol} / \mathrm{L}$ tartarate and $1.9 \mathrm{~N} \mathrm{NaOH})$.

Principle: Total bilirubin was determined in the presence of caffeine, which releases albumin bound bilirubin, by the reaction with diazotized sulphanilic acid.

Procedure: Reagent one $(0.2 \mathrm{ml})$ containing $29 \mathrm{mmol} / \mathrm{L}$ Sulphanilic acid and $0.17 \mathrm{~N} \mathrm{HCl}$ was pipetted into clean test tube in triplicates. Sodium Nitirte $(0.05 \mathrm{ml})$ and $1 \mathrm{ml}$ of reagent two $(0.26 \mathrm{~mol} / \mathrm{L}$ caffeine and $0.52 \mathrm{~mol} / \mathrm{L}$ sodium benzoate) were added respectively, after which the plasma $(0.2 \mathrm{ml})$ was added. The assay mixture was properly mixed and incubated for $10 \mathrm{~min}$. at room temperature. Reagent four $(1 \mathrm{ml})$ containing $0.93 \mathrm{~mol} / \mathrm{L}$ tartarate and $1.9 \mathrm{~N} \mathrm{NaOH}$ was added to the assay mixture immediately after incubation, vigorously mixed and incubated further for $30 \mathrm{~min}$. at $25^{\circ} \mathrm{C}$. The absorbance of the mixture was read at $578 \mathrm{~nm}$ against a sample blank prepared without sodium nitrite. The total bilirubin concentration was calculated using the expression;

Total bilirubin $(\mathrm{mg} / \mathrm{dl})=10.8 \times$ Asample $578 \mathrm{~nm}$

Estimation of Alkaline Phosphatase (ALP) Activity: The activity of ALP in plasma was assayed according to the method of Rec. GSCC, [22], using Randox Diagnostic Kit. The kit contained a substrate vial $(10 \mathrm{mmol} / \mathrm{L}$ p-nitrophenylphosphate) and buffer (100 mol/L Diethanolamine buffer, pH 9.8 and $0.5 \mathrm{mmol} / \mathrm{L}$ magnesium chloride).

Principle: ALP catalyses the hydrolysis of pnitrophenylphosphate to form $\mathrm{p}$-nitrophenol. The rate of formation of p-nitrophenol was monitored and measured 


\section{Open Access Journal of Pharmaceutical Research}

spectrophotometrically at $405 \mathrm{~nm}$ which is proportional to ALP activity.

$$
\begin{gathered}
\mathrm{p} \text { - nitrophenylphosphate }+\mathrm{H}_{2} \mathrm{O} \stackrel{\text { ALP }}{\longrightarrow} \mathrm{p} \text { - nitrophenol } \\
+ \text { phosphate }
\end{gathered}
$$

Procedure: Plasma $(0.1 \mathrm{ml})$ was pipetted into $1 \mathrm{~cm}$ cuvette at room temperature $\left(25^{\circ} \mathrm{C}\right)$ and the reaction was initiated by addition $0.5 \mathrm{ml}$ substrate. The initial absorbance was taken immediately at $405 \mathrm{~nm}$ and repeated for the first, second and third minutes consecutively. The change in absorbance/min was calculated. ALP activity was calculated by the expression; ALP activity $(\mathrm{U} / \mathrm{L})=2760 \times \mathrm{A} 405 \mathrm{~nm} / \mathrm{min}$

Estimation of Plasma Creatinine Concentration: Plasma creatinine was estimated according to the alkaline picrate method, as described by using Randox Diagnostic Kit.

Principle: Picric acid in alkaline medium reacts with creatinine to form an orange coloured complex. The intensity of the colour formed during the fixed time was directly proportional to the amount of creatinine present in the sample.

Creatinine+Alkaline picrate $\rightarrow$ Orange Coloured Complex

Procedure: The plasma $(0.05 \mathrm{ml})$ was pipetted into clean test tube and $0.5 \mathrm{ml}$ of the working reagent (consisted of $35 \mathrm{mmol} / \mathrm{L}$ Picric acid and $0.32 \mathrm{~mol} / \mathrm{L} \mathrm{NaOH}$ ) was added, mixed and the absorbance read at $492 \mathrm{~nm}$, after 30 seconds and 2 min consecutively against a reagent blank consisted of $0.05 \mathrm{ml}$ distilled water and $0.5 \mathrm{ml}$ of the working reagent. Creatinine concentration was calculated by the expression;

$$
\begin{aligned}
& \text { Creatinine concentration }(\mathrm{mg} / \mathrm{dL}) \\
& =\frac{\mathrm{Abs}_{\text {sample }}}{\mathrm{Abs}_{\text {standard }}} \times \text { Standard concentration }(\mathrm{mg} \\
& \quad / \mathrm{dL})
\end{aligned}
$$

Estimation of Plasma Uric Acid Concentration: Uric acid estimation was carried out according to the colorimetric method described by using Randox Diagnostic Kit. The kit contained enzyme reagent $(0.25$ mmol/L 4- Aminophenazone, Peroxidase $1000 \mathrm{U} / \mathrm{L}$, and Uricase $200 \mathrm{U} / \mathrm{L}$ ) and a buffer system (50 mmol/L, pH 7.0

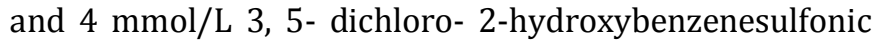
acid).

Principle: Uric acid was converted by uricase to allantoin with the formation of hydrogen peroxide, which under the catalytic influence of peroxidase, oxidized 3, 5-D-2- hydroxybenzenesulfonic acid and 4- aminophenazone form a quinoneimine dye proportional to the concentration of uric acid in the sample.

$$
\begin{gathered}
\text { Uric acid }+\mathrm{O}_{2}+2 \mathrm{H}_{2} \mathrm{O} \stackrel{\text { uricase }}{\longrightarrow} \text { Allantoin }+\mathrm{CO}_{2}+\mathrm{H}_{2} \mathrm{O}_{2} \\
2 \mathrm{H}_{2} \mathrm{O}_{2}+3,5-\text { dichloro }-2 \text { - hydroxybenzenesulfonic acid } \\
+4-\text { aminophenazone } \\
\mathrm{N}-(4-\text { antipyryl })-3-\text { chloro }-5-\text { peroxidase } \\
\text { - quinoneimine }
\end{gathered}
$$

Procedure: The working reagent was prepared by reconstituting $15 \mathrm{ml}$ of buffer solution into one vial of enzyme reagent. The plasma $(0.01 \mathrm{ml})$ was pipette into clean test tubes in triplicates and $0.5 \mathrm{ml}$ of the prepared working solution was added and mixed. The absorbance was read at $520 \mathrm{~nm}$ against a reagent blank and a standard.

by the expression;

Uric acid concentration was calculated Uric acid concentration $(\mathrm{mg} / \mathrm{dL})$

$$
\begin{aligned}
& =\frac{\mathrm{Abs}_{\text {sample }}}{\mathrm{Abs}_{\text {standard }}} \times \text { Standard concentration }(\mathrm{mg} \\
& / \mathrm{dL})
\end{aligned}
$$

\section{Plasma Lipid Profile}

The plasma lipid levels which included total cholesterol, triacylglycerol and high density lipoproteins cholesterol were carried out using available commercial kits (Randox Diagnostic Kits) while low density lipoprotein cholesterol (LDL-C) and very low density lipoprotein (VLDL-C) were calculated using Friedewald expression [22].

Estimation of Plasma Total Cholesterol Concentration: The total plasma cholesterol was estimated according to the method of using Randox Diagnostic Kit.

Principle: Cholesterol esterase hydrolysed esterified cholesterols to free cholesterol. The free cholesterol was oxidized to form hydrogen peroxide which further reacted with phenol and 4-aminoantipyrine by the catalytic action of peroxidase to form a red coloured dye complex. The intensity of the colour formed was directly proportional to the amount of cholesterol present in the sample.

$$
\begin{gathered}
\begin{array}{c}
\text { Cholesterol esters }+\mathrm{H}_{2} \mathrm{O} \stackrel{\text { Cholesterol Esterase }}{\longrightarrow} \text { Cholesterol } \\
+ \text { fatty acids }
\end{array} \\
\text { Cholesterol }+\mathrm{O}_{2} \stackrel{\text { Cholesterol oxidase }}{\longrightarrow} \text { Cholestenone }+\mathrm{H}_{2} \mathrm{O}_{2}
\end{gathered}
$$




\section{Open Access Journal of Pharmaceutical Research}

$$
\begin{aligned}
& \mathrm{H}_{2} \mathrm{O}_{2}+4 \text { - aminoantipyrine }+ \text { phenol } \\
& \stackrel{\text { Peroxidase }}{\longrightarrow} \text { Red Quinoneimine dye }+\mathrm{H}_{2} \mathrm{O}
\end{aligned}
$$

Procedure: The plasma $(0.05 \mathrm{ml})$ and distilled water $(0.05 \mathrm{ml})$ were pipetted into two separate test tubes for the test sample and reagent blank respectively. The working reagent $(0.5 \mathrm{ml})$ consisted of 4 - Aminoantipyrine $(0.30 \mathrm{mmol} / \mathrm{L})$, phenol $(6 \mathrm{mmol} / \mathrm{L})$ peroxidase $(>0.5$ $\mathrm{U} / \mathrm{ml})$, cholesterol esterase $(>0.15 \mathrm{U} / \mathrm{ml})$, cholesterol oxidase $(>0.1 \mathrm{U} / \mathrm{ml})$ and pipes buffer $(80 \mathrm{mmol} / \mathrm{L}$; $\mathrm{pH} 6.8)$ was added, mixed and incubated at $20-25^{\circ} \mathrm{C}$ for $10 \mathrm{~min}$. The same procedure was repeated with $0.01 \mathrm{ml}$ of the standard solution and the absorbance was taken at $500 \mathrm{~nm}$ within 60 min against the blank. Plasma total cholesterol concentration was calculated using the expression below;

Total cholesterol concentration

$$
\begin{aligned}
& =\frac{\mathrm{Abs}_{\text {sample }}}{\mathrm{Abs}} \text { standard } \\
& / \mathrm{dL})
\end{aligned}
$$

Estimation of Plasma Triglycerides Concentration: Plasma triglyceride was estimated according to the method of Tietz [23], using Randox Diagnostic Kit. The kit contained a buffer solution consisted of pipes buffer (40 $\mathrm{mmol} / \mathrm{L} \mathrm{pH} \mathrm{7.6),} \mathrm{4-} \mathrm{Chloro-phenol} \mathrm{(5.5} \mathrm{mmol/L)} \mathrm{and}$ magnesium ions (17.5 mmol/L). An enzyme reagent, consisted of 4-aminophenazone $(0.5 \mathrm{mmol} / \mathrm{L})$, ATP $(1.0$ $\mathrm{mmol} / \mathrm{L})$, Lipases (>150 U/ml), Glycerol-kinase (> $0.4 \mathrm{U} / \mathrm{ml})$, Glycerol-3-phosphate oxidase $(>1.5 \mathrm{U} / \mathrm{ml})$ and peroxidase $(>0.5 \mathrm{U} / \mathrm{ml})$.

Principle: Lipoprotein lipase hydrolyses triglycerides to glycerol and free fatty acids. The glycerol formed with ATP in the presence of glycerol kinase forms glycerol-3phosphate, which is oxidized by the enzyme glycerol phosphate oxidase to form hydrogen peroxide. The hydrogen peroxide further reacts with phenolic compound and 4-aminoantipyrine by the catalytic action of peroxidase to form a red colored quinoneimine dye complex. The intensity of the colour formed is directly proportional to the amount of triglycerides present in the sample.

$$
\begin{gathered}
\text { Triglycerides } \underset{\text { Lipoprotein Lipase }}{\longrightarrow} \text { Glycerol + free fatty acids } \\
\text { Glycerol + ATP } \stackrel{\text { Glycerol Kinase }}{\longrightarrow} \text { Glycerol }-3 \text { - phosphate + ADP } \\
\text { Glycerol - 3- phoshate }+\mathrm{O}_{2} \\
\stackrel{\substack{\text { Glycerol 3 PO } \\
+\mathrm{H}_{2} \mathrm{O}_{2}}}{\longrightarrow} \text { Dihydroxyacetone Phosphate }
\end{gathered}
$$

$$
\begin{aligned}
\mathrm{H}_{2} \mathrm{O}_{2}+4-\text { aminoantipyrine } & \\
& + \text { phenol } \stackrel{\text { Peroxidase }}{\longrightarrow} \text { Red Quinoneimine dye } \\
& +\mathrm{H}_{2} \mathrm{O}
\end{aligned}
$$

Procedure: A working reagent was prepared by reconstituting $15 \mathrm{ml}$ of the buffer into one vial enzyme bottle. The plasma $(0.01 \mathrm{ml})$ and distilled water $(0.01 \mathrm{ml})$ were pipetted into two separate test tubes for the test sample and reagent blank respectively. Working reagent $(0.5 \mathrm{ml})$ was added, mixed thoroughly and incubated at $20-25^{\circ} \mathrm{C}$ for $10 \mathrm{~min}$. The same procedure was repeated with $0.01 \mathrm{ml}$ of the standard solution and the absorbance was taken at 500nm within $60 \mathrm{~min}$. The triglyceride concentration was calculated using the expression below;

Triglycerides concentration $(\mathrm{mg} / \mathrm{dL})$

$$
\begin{aligned}
& =\frac{\mathrm{Abs}_{\text {sample }}}{\mathrm{Abs}_{\text {standard }}} \times \text { Standard concentration (mg } \\
& / \mathrm{dL})
\end{aligned}
$$

Estimation of Plasma High-Density Lipoprotein Cholesterol (HDL-C) Concentration: The estimation of plasma HDL-c was carried out according to the method described by Friedewal d, et al. [22], using Randox Diagnostic Kit. The method of estimation was in two phases; first, HDL was precipitated from the sample (plasma), after which the precipitate was used for HDL estimation using Cholesterol Randox Diagnostic Kit.

Procedure: The plasma and standard $(0.2 \mathrm{ml})$ were precipitated with $0.5 \mathrm{ml}$ precipitating reagent $(0.55$ mmol/L phosphotungstic acid and Manganese Chloride $(25 \mathrm{mmol} / \mathrm{L}))$ and allowed to settle at room temperature for $10 \mathrm{~min}$. The suspension was centrifuged at $4000 \mathrm{rpm}$ for $10 \mathrm{~min}$. and the clear supernatant was carefully collected and used for HDL-c estimation.

The supernatant of the sample and standard $(0.1 \mathrm{ml})$ were separately pipette into clean test tubes for HDL-c estimation. Reagent solution ( $\mathrm{I} \mathrm{ml}$ ) was added, mixed and incubated at room temperature for $10 \mathrm{~min}$. The absorbance of the reaction mixture and standard were read at $500 \mathrm{~nm}$ against the reagent blank containing distilled water in place of reagent solution. The plasma HDL-c was calculated from the expression;

$$
\begin{aligned}
& \mathrm{HDL} \text { - c concentration }(\mathrm{mg} / \mathrm{dL}) \\
& \qquad \frac{\mathrm{Abs}_{\text {sample }}}{\mathrm{Abs}_{\text {standard }}} \mathrm{XStandard} \text { concentration }(\mathrm{mg} \\
& / \mathrm{dL})
\end{aligned}
$$




\section{Open Access Journal of Pharmaceutical Research}

Estimation of Plasma Low-Density Lipoprotein Cholesterol (LDL-C) Concentration: Low density lipoprotein cholesterol (LDL-C) and very low density lipoprotein (VLDL-C) were calculated via Friedewald estimation [22].

Using the following expressions;

$$
\mathrm{LDL}_{-\mathrm{c}}=\mathrm{TC}-\left(\frac{\mathrm{TG}}{5}+\mathrm{HDL}_{-\mathrm{c}}\right) \mathrm{mg} / \mathrm{dl}
$$

Where $\mathrm{TC}=$ Total cholesterol, $\mathrm{TG}=$ Triglycerides

\section{Statistical Analysis}

Data were expressed as Mean \pm standard error of mean, $n=5$. The presence of significant differences among means of groups was determined by One-way Analysis of

Variance (ANOVA), using Graph Pad Prism (Graph Pad Software, San Diego, CA, USA). Differences were considered to be significant if $\mathrm{p}<0.05$.

\section{Results}

\section{In-vivo Toxicity Assessment of Spondias mombinon Albino Rats}

Effect of Spondias mombin Stem Bark Extracts on Body Weight Gained of Rats at 200 and $500 \mathrm{mg} / \mathrm{Kg}$ : Table 1 shows the effect of Spondias mombin stem bark extracts on body weights and food consumption of albino rats. The table reveals the weight of albino rats from 0 day to 21 days. It was observed that the weight of the rats ranged

from 94.35 to $138.88 \mathrm{~g}$. After 21 days, the body weight gained by the rats in the three experimental groups $A$ to $D$ were significantly different from control at $p<0.05$ as the body weight reduced drastically.

Effect of Spondias mombin Stem Bark Extracts on Weekly Albino Rats' Food Consumption (G) and Water Intake $(200$ and $500 \mathrm{mg} / \mathbf{K g})$ : The effect of Spondias mombin stem bark extracts on weekly food and water intake on rats is presented in table 2. There was a reduction in the food consumption rate while water intake reduced at the end of 21 days administration. There was a significant difference in food and water consumption parameters in group $\mathrm{A}$ to $\mathrm{C}$ and that of control group at $\mathrm{p}<0.05$.

Effect of Spondias mombin Stem Bark Extracts on Organs Weight and Haematological Indices of Albino Rats: The effect of Spondias mombin stem bark extracts on various organs of albino rats after 21 days of administration of the extract at 200 and $500 \mathrm{mg} / \mathrm{kg}$ is shown in table $3 \mathrm{a}$ and $3 \mathrm{~b}$. There were no statistical significant differences in the values of WBC, HB, HCT, $\mathrm{MCV}, \mathrm{MCH}, \mathrm{MCHC}$ counts between rats from all treated and control groups $\mathrm{p}<0.05$. However, there was a significant difference in the RBC and PLT counts in the experimental compared to control group after the 21 days of extract administration $(\mathrm{P}>0.01)$ as the RBC and PLT increased in the experimental groups in table $4 \mathrm{~A}$ and $4 \mathrm{~b}$.

\begin{tabular}{|c|c|c|c|c|c|c|c|c|}
\hline DAY & $\mathbf{A}(\mathbf{2 0 0} \mathbf{m g} / \mathbf{k g})$ & $\mathbf{A}(\mathbf{5 0 0} \mathbf{m g} / \mathbf{k g})$ & $\mathbf{B}(\mathbf{2 0 0} \mathbf{m g} / \mathbf{k g})$ & $\mathbf{B}(\mathbf{5 0 0} \mathbf{m g} / \mathbf{k g})$ & $\mathbf{C}(\mathbf{2 0 0} \mathbf{m g} / \mathbf{k g})$ & $\mathbf{C}(\mathbf{5 0 0} \mathbf{m g} / \mathbf{k g})$ & $\mathbf{D}(\mathbf{2 0 0} \mathbf{m g} / \mathbf{k g})$ & $\mathbf{D}(\mathbf{5 0 0} \mathbf{m g} / \mathbf{k g})$ \\
\hline $\mathbf{0}$ & 128.4 & 12956 & 124.8 & 128.8 & 134.88 & 141 & 125.6 & 124 \\
\hline 7 & 126.66 & 127.21 & 122.47 & 121.48 & 128.16 & 129.43 & 130.02 & 130 \\
\hline 14 & 126.28 & 127,31 & $119.90^{*}$ & $121.00^{*}$ & $118.90^{*}$ & 120.98 & 138.1 & 137.9 \\
\hline 21 & $94.35^{*}$ & 90.34 & $99.48^{*}$ & $102.40^{*}$ & $97.71^{*}$ & 100.43 & 148.48 & 145.21 \\
\hline
\end{tabular}

Table 1: Effect of Spondias mombin Stem Bark Extracts on Body Weights of Albino Rats.

Body weight gained (g) Treatment

Mean \pm SEM. * significantly different from control at $p<0.05$.

Key:

$\mathbf{A}=200 \mathrm{mg} / \mathrm{kg}$ and $500 \mathrm{mg} / \mathrm{kg}$ body weight doses of crude aqueous stem bark extract of Spondias mombin,

$\mathbf{B}=200 \mathrm{mg} / \mathrm{kg}$ and $500 \mathrm{mg} / \mathrm{kg}$ body weight doses of crude ethanolic stem bark extract of Spondias mombin

$\mathrm{C}=200 \mathrm{mg} / \mathrm{kg}$ and $500 \mathrm{mg} / \mathrm{kg}$ body weight doses of crude ethyl acetate stem bark extracts of Spondias mombin

$\mathrm{D}=$ Control 


\section{Open Access Journal of Pharmaceutical Research}

\begin{tabular}{|c|c|c|c|c|c|c|c|c|c|c|c|c|}
\hline \multirow[b]{2}{*}{ Treatment } & \multicolumn{4}{|c|}{ WEEK I } & \multicolumn{4}{|c|}{ WEEK 2} & \multicolumn{4}{|c|}{ WEEK 3} \\
\hline & $\begin{array}{l}\text { Food consumed } \\
\text { (g) }(200 \mathrm{mg} / \mathrm{kg})\end{array}$ & $\begin{array}{l}\text { Food consumed } \\
\text { (g) }(500 \mathrm{mg} / \mathrm{kg})\end{array}$ & $\begin{array}{l}\text { Water intake } \\
(200 \mathrm{mg} / \mathrm{kg})\end{array}$ & $\begin{array}{l}\text { Water intake } \\
500 \mathrm{mg} / \mathrm{kg})\end{array}$ & $\begin{array}{l}\text { Food consumed } \\
\text { (g) }(200 \mathrm{mg} / \mathrm{kg})\end{array}$ & $\begin{array}{c}\text { Food } \\
\text { consumed (g) } \\
(500 \mathrm{mg} / \mathrm{kg})\end{array}$ & $\begin{array}{l}\text { Water intake } \\
(200 \mathrm{mg} / \mathrm{kg})\end{array}$ & $\left|\begin{array}{l}\text { Water intake } \\
(500 \mathrm{mg} / \mathrm{kg})\end{array}\right| \mathrm{C}$ & $\begin{array}{c}\text { Food } \\
\text { consumed }(\mathrm{g}) \\
(200 \mathrm{mg} / \mathrm{kg})\end{array}$ & $\begin{array}{c}\text { Food } \\
\text { consumed }(\mathrm{g}) \\
(500 \mathrm{mg} / \mathrm{kg})\end{array}$ & $\left\{\begin{array}{l}\text { Water intake } \\
(200 \mathrm{mg} / \mathrm{kg})\end{array}\right.$ & $\begin{array}{l}\text { Water intake } \\
(500 \mathrm{mg} / \mathrm{kg})\end{array}$ \\
\hline $\mathbf{A}$ & $128.00 \pm 18.06^{*}$ & $129.00 \pm 18.07^{*}$ & $170.40 \pm 4.83$ & $171.40 \pm 4.94$ & $112.22 \pm 16.44$ & $110.22 \pm 15.44$ & $170.84 \pm 6.28 *$ & $170.64 \pm 6.28$ & $107.15 \pm 9.64$ & $108.15 \pm 9.65$ & $174.60 \pm 5.22$ & $176.60 \pm 6.22$ \\
\hline B & $124.04 \pm 17.28$ & $125.04 \pm 17.28$ & $163.98 \pm 8.85$ & $165.98 \pm 8.80$ & $100.04 \pm 14.08$ & $100.09 \pm 16.08$ & $167.50 \pm 3.86$ & $157.50 \pm 3.87$ & $95.46 \pm 7.86$ & $90.46 \pm 7.87$ & $172.00 \pm 8.02$ & $170.00 \pm 8.05$ \\
\hline $\mathbf{C}$ & $120.06 \pm 12.28$ & $122.06 \pm 12.30$ & $162.22 \pm 4.04$ & $160.22 \pm 4.05$ & $104.06 \pm 16.72^{*}$ & $106.06 \pm 14.73$ & $164.90 \pm 7.25$ & $167.90 \pm 7.20 *$ & $98.57 \pm 7.68$ & $100.57 \pm 7.68$ & $178.50 \pm 7.23$ & $175.50 \pm 7.20$ \\
\hline D & $126.52 \pm 16.82^{*}$ & $136.52 \pm 16.81^{*}$ & $175.60 \pm 4.65$ & $170.60 \pm 4.68$ & $120.60 \pm 17.28$ & $122.60 \pm 17.30$ & $170.40 \pm 5.24$ & $172.40 \pm 5.201$ & $116.76 \pm 7.86^{*}$ & $117.76 \pm 6.86 *$ & $158.60 \pm 8.05 *$ & $* 168.60 \pm 9.05^{*}$ \\
\hline
\end{tabular}

Table 2: Effect of Spondias mombin Stem Bark Extracts on Weekly Albino rats' Food Consumption (G) and Water Intake (200 500mg/Kg).

Mean \pm SEM. *Significantly Different From Control at $\mathrm{P}<0.05$.

\begin{tabular}{|c|c|c|c|c|c|c|c|c|c|c|c|c|}
\hline \multicolumn{9}{|c|}{ WEEK I } & \multicolumn{9}{c|}{ WEEK 2 } & \multicolumn{4}{c|}{ WEEK 3 } \\
\hline Organs & $\mathbf{1 A}$ & $\mathbf{1 B}$ & $\mathbf{1 C}$ & $\mathbf{1 D}$ & $\mathbf{2 A}$ & $\mathbf{2 B}$ & $\mathbf{2 C}$ & 2D & 3A & 3B & 3C & 3D \\
\hline Brain & $1.02 \pm 0.04$ & $1.00 \pm 0.05$ & $0.98 \pm 0.02$ & $1.08 \pm 0.05$ & $1.01 \pm 0.04$ & $1.00 \pm 0.05$ & $0.97 \pm 0.02$ & $1.08 \pm 0.05$ & $1.05 \pm 0.04$ & $1.00 \pm 0.05$ & $0.70 \pm 0.02$ & $1.06 \pm 0.05$ \\
\hline Heart & $0.74 \pm 0.03$ & $0.72 \pm 0.04$ & $0.76 \pm 0.03$ & $0.84 \pm 0.06$ & $0.72 \pm 0.03$ & $0.74 \pm 0.04$ & $0.76 \pm 0.03$ & $0.84 \pm 0.06$ & $0.74 \pm 0.03$ & $0.72 \pm 0.04$ & $0.80 \pm 0.03$ & $0.84 \pm 0.06$ \\
\hline Kidneys & $0.65 \pm 0.01$ & $0.58 \pm 0.02$ & $0.65 \pm 0.02$ & $0.68 \pm 0.01$ & $0.65 \pm 0.01$ & $0.59 \pm 0.02$ & $0.67 \pm 0.02$ & $0.68 \pm 0.01$ & $0.65 \pm 0.01$ & $0.58 \pm 0.02$ & $0.65 \pm 0.02$ & $0.67 \pm 0.01$ \\
\hline Spleen & $0.43 \pm 0.03$ & $0.41 \pm 0.01^{*}$ & $0.50 \pm 0.040$ & $0.53 \pm 0.04$ & $0.43 \pm 0.03$ & $0.41 \pm 0.01^{*}$ & $0.50 \pm 0.040$ & $0.53 \pm 0.04$ & $0.43 \pm 0.03$ & $0.41 \pm 0.01 *$ & $0.60 \pm 0.040$ & $0.72 \pm 0.04$ \\
\hline Liver & $3.56 \pm 0.08$ & $3.44 \pm 0.06$ & $3.62 \pm 0.08$ & $3.85 \pm 0.11$ & $3.51 \pm 0.08$ & $3.48 \pm 0.06$ & $3.65 \pm 0.08$ & $3.85 \pm 0.11$ & $3.56 \pm 0.08$ & $3.44 \pm 0.06$ & $3.62 \pm 0.08$ & $3.90 \pm 0.11$ \\
\hline Stomach & $1.10 \pm 0.18$ & $1.10 \pm 0.10$ & $1.20 \pm 0.22$ & $1.29 \pm 0.10$ & $1.10 \pm 0.18$ & $1.12 \pm 0.10$ & $1.27 \pm 0.22$ & $1.29 \pm 0.10$ & $1.10 \pm 0.18$ & $1.10 \pm 0.10$ & $1.20 \pm 0.22$ & $1.42 \pm 0.10$ \\
\hline Testes & $1.70 \pm 0.03$ & $1.66 \pm 0.08$ & $1.74 \pm 0.11$ & $1.75 \pm 0.07$ & $1.70 \pm 0.03$ & $1.66 \pm 0.08$ & $1.74 \pm 0.11$ & $1.75 \pm 0.07$ & $1.70 \pm 0.03$ & $1.66 \pm 0.08$ & $1.74 \pm 0.11$ & $1.85 \pm 0.07$ \\
\hline
\end{tabular}

Table 3a: Effect of Spondias mombin Stem Bark Extracts on Organ Weight of Albino rats Intake $(200 \mathrm{mg} / \mathrm{Kg})$.

Mean \pm SEM. *significantly different from control at $\mathrm{p}<0.05$. 
Open Access Journal of Pharmaceutical Research

\begin{tabular}{|c|c|c|c|c|c|c|c|c|c|c|c|c|}
\hline \multicolumn{5}{|c|}{ WEEK I } & \multicolumn{4}{|c|}{ WEEK 2} & \multicolumn{4}{|c|}{ WEEK 3} \\
\hline Organs & $1 \mathrm{~A}$ & 1B & $1 \mathrm{C}$ & 1D & $2 A$ & 2B & $2 \mathrm{C}$ & 2D & $3 A$ & 3B & $3 C$ & 3D \\
\hline Brain & $1.02 \pm 0.04$ & $1.00 \pm 0.05$ & $100.98 \pm 0.01$ & $1.08 \pm 0.05$ & $1.00 \pm 0.04$ & $1.00 \pm 0.05$ & $0.96 \pm 0.02$ & $1.08 \pm 0.05$ & $1.06 \pm 0.04$ & $1.00 \pm 0.05$ & $0.70 \pm 0.02$ & $1.06 \pm 0.05$ \\
\hline Heart & $0.70 \pm 0.03$ & $0.72 \pm 0.04$ & $0.76 \pm 0.03$ & $0.74 \pm 0.05$ & $0.71 \pm 0.03$ & $0.74 \pm 0.04$ & $0.76 \pm 0.03$ & $0.94 \pm 0.06$ & $0.73 \pm 0.03$ & $0.72 \pm 0.04$ & $0.81 \pm 0.03$ & $0.84 \pm 0.06$ \\
\hline Kidneys & $0.55 \pm 0.01$ & $0.58 \pm 0.02$ & $0.65 \pm 0.02$ & $0.60 \pm 0.01$ & $0.75 \pm 0.01$ & $0.59 \pm 0.02$ & $0.67 \pm 0.02$ & $0.78 \pm 0.01$ & $0.75 \pm 0.01$ & $0.58 \pm 0.02$ & $0.67 \pm 0.02$ & $0.67 \pm 0.01$ \\
\hline Spleen & $0.43 \pm 0.03$ & $0.41 \pm 0.01 *$ & $0.50 \pm 0.040$ & $0.63 \pm 0.04$ & $0.43 \pm 0.03$ & $0.41 \pm 0.01 *$ & $0.50 \pm 0.040$ & $0.53 \pm 0.04$ & $0.43 \pm 0.03$ & $0.41 \pm 0.01 *$ & $0.60 \pm 0.040$ & $0.72 \pm 0.04$ \\
\hline Liver & $3.56 \pm 0.08$ & $3.44 \pm 0.06$ & $3.62 \pm 0.08$ & $3.85 \pm 0.11$ & $3.51 \pm 0.08$ & $3.48 \pm 0.06$ & $3.65 \pm 0.08$ & $3.85 \pm 0.11$ & $3.56 \pm 0.08$ & $3.44 \pm 0.06$ & $3.62 \pm 0.08$ & $3.90 \pm 0.11$ \\
\hline Stomach & $1.00 \pm 0.18$ & $1.10 \pm 0.10$ & $1.30 \pm 0.22$ & $1.29 \pm 0.11$ & $1.00 \pm 0.18$ & $1.12 \pm 0.10$ & $1.37 \pm 0.22$ & $1.29 \pm 0.10$ & $1.00 \pm 0.18$ & $1.10 \pm 0.10$ & $1.30 \pm 0.22$ & $1.42 \pm 0.10$ \\
\hline Testes & $1.60 \pm 0.03$ & $1.56 \pm 0.08$ & $1.74 \pm 0.11$ & $1.75 \pm 0.07$ & $1.70 \pm 0.03$ & $1.65 \pm 0.08$ & $1.74 \pm 0.11$ & $1.75 \pm 0.07$ & $1.70 \pm 0.03$ & $1.65 \pm 0.08$ & $1.75 \pm 0.11$ & $1.85 \pm 0.07$ \\
\hline
\end{tabular}

Table 3b: Effect of Spondias mombin Stem Bark Extracts on Organ Weight of Albino rats Intake (500mg/Kg)

Mean \pm SEM. *significantly different from control at $\mathrm{p}<0.05$

\begin{tabular}{|c|c|c|c|c|c|c|c|c|c|c|c|c|}
\hline \multirow{2}{*}{$\begin{array}{c}\text { Blood } \\
\text { indices }\end{array}$} & \multicolumn{4}{|c|}{ WEEK I } & \multicolumn{4}{|c|}{ WEEK 2} & \multicolumn{4}{|c|}{ WEEK 3} \\
\hline & $1 \mathrm{~A}$ & 1B & $1 \mathrm{C}$ & 1D & $2 \mathrm{~A}$ & 2B & $2 \mathrm{C}$ & 2D & $3 \mathrm{~A}$ & $3 B$ & $3 \mathrm{C}$ & 3D \\
\hline $\mathrm{RBC}$ & $7.93 \pm 0.22$ & $8.85 \pm 0.22$ & $8.11 \pm 0.34$ & $7.44 \pm 0.38$ & $6.93 \pm 0.22$ & $8.89 \pm 0.22$ & $8.13 \pm 0.34$ & $7.48 \pm 0.38$ & $7.93 \pm 0.22$ & $8.85 \pm 0.22$ & $9.11 \pm 0.34$ & $7.54 \pm 0.38$ \\
\hline WBC & $\begin{array}{c}18.78 \pm 1.3 \\
9\end{array}$ & $19.32 \pm 1.76$ & $\begin{array}{c}23.80 \pm 2.4 \\
5\end{array}$ & $\begin{array}{c}19.58 \pm 3.5 \\
0\end{array}$ & $\begin{array}{c}18.78 \pm 1.3 \\
9\end{array}$ & $19.37 \pm 1.76$ & $\begin{array}{c}23.84 \pm 2.4 \\
5\end{array}$ & $\begin{array}{c}20.58 \pm 3.5 \\
0\end{array}$ & $\begin{array}{c}18.78 \pm 1.3 \\
9\end{array}$ & $19.32 \pm 1.76$ & $\begin{array}{c}23.80 \pm 2.4 \\
5\end{array}$ & $\begin{array}{c}20.58 \pm 3.5 \\
0\end{array}$ \\
\hline HB & $\begin{array}{c}12.20 \pm 0.2 \\
6\end{array}$ & $13.28 \pm 0.26$ & $\begin{array}{c}12.26 \pm 0.4 \\
5\end{array}$ & $\begin{array}{c}11.68 \pm 0.5 \\
9\end{array}$ & $\begin{array}{c}12.24 \pm 0.2 \\
6\end{array}$ & $13.78 \pm 0.26$ & $\begin{array}{c}14.26 \pm 0.4 \\
5\end{array}$ & $\begin{array}{c}12.68 \pm 0.5 \\
9\end{array}$ & $\begin{array}{c}12.20 \pm 0.2 \\
6\end{array}$ & $13.28 \pm 0.26$ & $\begin{array}{c}12.26 \pm 0.4 \\
5\end{array}$ & $\begin{array}{c}12.68 \pm 0.5 \\
9\end{array}$ \\
\hline HCT & $\begin{array}{c}49.74 \pm 1.7 \\
8 \\
\end{array}$ & $\begin{array}{c}54.30 \pm 1.45 \\
* \\
\end{array}$ & $\begin{array}{c}50.76 \pm 1.4 \\
1 \\
\end{array}$ & $\begin{array}{c}45.78 \pm 2.6 \\
9 \\
\end{array}$ & $\begin{array}{c}49.74 \pm 1.7 \\
8 \\
\end{array}$ & $53.30 \pm 1.45$ & $\begin{array}{c}51.76 \pm 1.4 \\
1 \\
\end{array}$ & $\begin{array}{c}45.78 \pm 2.6 \\
9 \\
\end{array}$ & $\begin{array}{c}49.74 \pm 1.7 \\
8 \\
\end{array}$ & $54.30 \pm 1.45$ & $\begin{array}{c}50.76 \pm 1.4 \\
1 \\
\end{array}$ & $\begin{array}{c}46.78 \pm 2.6 \\
9 \\
\end{array}$ \\
\hline MCV & $\begin{array}{c}62.66 \pm 1.3 \\
0 \\
\end{array}$ & $62.78 \pm 0.77$ & $\begin{array}{c}61.48 \pm 1.3 \\
0 \\
\end{array}$ & $\begin{array}{c}61.46 \pm 0.9 \\
6 \\
\end{array}$ & $\begin{array}{c}62.66 \pm 1.3 \\
0 \\
\end{array}$ & $62.78 \pm 0.77$ & $\begin{array}{c}61.48 \pm 1.3 \\
0 \\
\end{array}$ & $\begin{array}{c}62.46 \pm 0.9 \\
6 \\
\end{array}$ & $\begin{array}{c}62.66 \pm 1.3 \\
0 \\
\end{array}$ & $\begin{array}{c}62.78 \pm 0.77 \\
* \\
\end{array}$ & $\begin{array}{c}61.48 \pm 1.3 \\
0 \\
\end{array}$ & $\begin{array}{c}63.46 \pm 0.9 \\
6 \\
\end{array}$ \\
\hline $\mathrm{MCH}$ & $\begin{array}{c}15.42 \pm 0.2 \\
2 \\
\end{array}$ & $15.02 \pm 0.13$ & $\begin{array}{c}15.14 \pm 0.2 \\
2^{*}\end{array}$ & $\begin{array}{c}15.70 \pm 0.2 \\
0 \\
\end{array}$ & $\begin{array}{c}15.45 \pm 0.2 \\
2 \\
\end{array}$ & $\begin{array}{c}15.07 \pm 0.13 \\
* \\
\end{array}$ & $\begin{array}{c}15.17 \pm 0.2 \\
2 \\
\end{array}$ & $\begin{array}{c}15.76 \pm 0.2 \\
0\end{array}$ & $\begin{array}{c}15.42 \pm 0.2 \\
2 \\
\end{array}$ & $15.02 \pm 0.13$ & $\begin{array}{c}15.14 \pm 0.2 \\
2^{*} \\
\end{array}$ & $\begin{array}{c}17.70 \pm 0.2 \\
0 \\
\end{array}$ \\
\hline $\mathrm{MCHC}$ & $\begin{array}{c}24.58 \pm 0.4 \\
6\end{array}$ & $24.50 \pm 0.33$ & $\begin{array}{c}24.14 \pm 0.2 \\
8\end{array}$ & $\begin{array}{c}25.58 \pm 0.3 \\
2\end{array}$ & $\begin{array}{c}24.58 \pm 0.4 \\
6\end{array}$ & $24.50 \pm 0.33$ & $\begin{array}{c}24.14 \pm 0.2 \\
8^{* *}\end{array}$ & $\begin{array}{c}25.58 \pm 0.3 \\
2\end{array}$ & $\begin{array}{c}24.58 \pm 0.4 \\
6\end{array}$ & $24.50 \pm 0.33$ & $\begin{array}{c}24.14 \pm 0.2 \\
8 \\
\end{array}$ & $\begin{array}{c}25.58 \pm 0.3 \\
2\end{array}$ \\
\hline PLT & $\begin{array}{c}920.00 \pm 51 \\
.47\end{array}$ & $\begin{array}{c}1078.80 \pm 78 \\
.09\end{array}$ & $\begin{array}{c}939.00 \pm 43 \\
.91\end{array}$ & $\begin{array}{c}907.60 \pm 49 \\
.14\end{array}$ & $\begin{array}{c}920.00 \pm 51 \\
.47\end{array}$ & $\begin{array}{c}1078.80 \pm 78 \\
.09\end{array}$ & $\begin{array}{c}939.00 \pm 43 \\
.91\end{array}$ & $\begin{array}{c}908.60 \pm 49 \\
.14\end{array}$ & $\begin{array}{c}920.00 \pm 51 \\
.47\end{array}$ & $\begin{array}{c}1078.80 \pm 78 \\
.09\end{array}$ & $\begin{array}{c}939.00 \pm 43 \\
.91\end{array}$ & $\begin{array}{c}907.60 \pm 49 \\
.14\end{array}$ \\
\hline
\end{tabular}

Table 4a: Effect of Spondias mombin Stem Bark Extracts on Haematological Indices of Male \& Female Albino rats (200 mg/kg).

Mean \pm SEM. *significantly different from control at $\mathrm{p}<0.05$ 
Open Access Journal of Pharmaceutical Research

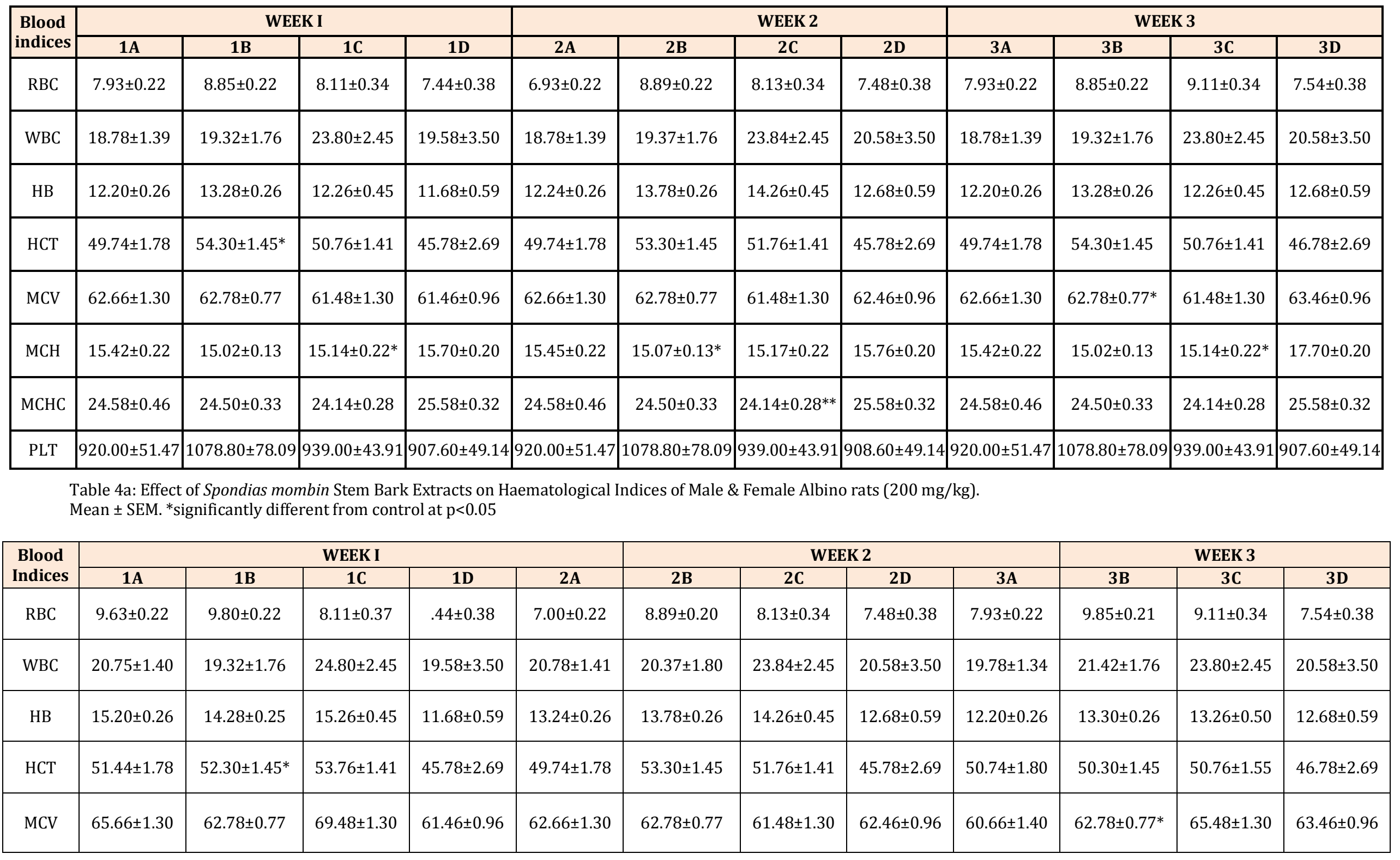


Open Access Journal of Pharmaceutical Research

\begin{tabular}{|c|c|c|c|c|c|c|c|c|c|c|c|c|}
\hline $\mathrm{MCH}$ & $18.42 \pm 0.22$ & $19.02 \pm 0.13$ & $15.14 \pm 0.22 *$ & $15.70 \pm 0.20$ & $15.45 \pm 0.22$ & $15.07 \pm 0.13^{*}$ & $16.17 \pm 0.22$ & $15.76 \pm 0.20$ & $17.42 \pm 0.22$ & $16.02 \pm 0.16$ & $15.14 \pm 0.22^{*}$ & $17.70 \pm 0.20$ \\
\hline $\mathrm{MCHC}$ & $28.58 \pm 0.46$ & $22.50 \pm 0.33$ & $26.14 \pm 0.28$ & $25.58 \pm 0.32$ & $24.58 \pm 0.46$ & $24.50 \pm 0.33$ & $24.14 \pm 0.28^{* *}$ & $25.58 \pm 0.32$ & $25.58 \pm 0.50$ & $25.50 \pm 0.33$ & $25.14 \pm 0.30$ & $25.58 \pm 0.32$ \\
\hline PLT & $925.00 \pm 51.47$ & $1078.80 \pm 78.09$ & $940.00 \pm 43.91$ & $906.60 \pm 49.14$ & $920.00 \pm 51.47$ & $1073.80 \pm 78.09$ & $939.00 \pm 43.91$ & $908.60 \pm 49.14$ & $921.00 \pm 51.47$ & $1071.80 \pm 78.09$ & $939.00 \pm 43.91$ & $907.60 \pm 49.14$ \\
\hline
\end{tabular}

Table 4b: Effect of Spondias mombin Stem Bark Extracts on Haematological Indices of Male \& Female Albino rats (500 mg/kg).

Mean \pm SEM. *significantly different from control at $\mathrm{p}<0.05$

KEY: RBC-Red blood cell MCV- Mean cell volume WBC = White blood cell MCH - Mean cell haemoglobin HB - Hemoglobin MCHC -Mean cell haemoglobin concentration HCT - Hematocrit PLT-Platelet.

\section{Liver and Kidney Biochemical Parameters of Rats Treated with Stem} Bark Extracts of Spondias mombin: Table 5A and B depict the effects of stem bark extracts of Spondias mombin on the various liver biochemical indices of rats. There were statistical significant differences in the values of cholesterol, TP, LDL, TAG, ALB, AST, ALT, ALP in the treated rats compared to the control group $(p<0.05$. All the parameters drastically reduced in the treated rats compared to the control. There was a marked significant difference in group $\mathrm{B}$ compared to control $(\mathrm{P}<0.01)$. Meanwhile, there was a profound increase in the kidney indices (sodium, potassium, chloride, bio carbonate, urea and creatinine) of the treated rats compared to the control during the $2^{\text {nd }}$ and $3^{\text {rd }}$ week of treatment $(\mathrm{P}<0.01)$.
Table 6A and B; Shows the Serum biochemical parameters of albino rats treated with Stem Bark extracts of Spondias mombin in week one, two and week three. The serum biochemical parameters investigated in this table are Cholesterol $\left(\mathrm{mmolL}^{-1}\right), \mathrm{TAG}\left(\mathrm{mmolL}^{-1}\right), \mathrm{HDL}\left(\mathrm{mmolL}^{-1}\right)$, LDL(mmolL1), Total protein $\mathrm{TP}\left(\mathrm{mmolL}^{-1}\right)$, ALB $\left(\mathrm{gL}^{-1}\right)$, Aspartate amino AST $\left(\mu \mathrm{molL}^{-1}\right)$, Alanine amino transferase ALT $\left(\mu \mathrm{molL}^{-1}\right)$, Sodium $\left(\mathrm{mmolL}^{-1}\right)$, Alkaline phosphatase ALP $\left(\mu \mathrm{molL}^{-1}\right)$, Potassium $\left(\mathrm{mmolL}^{-1}\right)$, Chloride $\left(\mathrm{mmolL}^{-1}\right)$, Bicarbonate $\left(\mathrm{mmolL}^{-1}\right)$, Urea $\left(\mathrm{mmolL}^{-1}\right)$ and Creatinine $\left(\mathrm{mmolL}^{-1}\right)$. In each group A to D recorded, Table were analyzed statistically Mean \pm SEM. **significantly different from control at $p<0.05$ for week one, Mean \pm SEM. ** significantly different from control at $\mathrm{p}<0.05$ for week two and Mean \pm SEM. ${ }^{* *}$ significantly different from control at $\mathrm{p}<0$ for week three.

\begin{tabular}{|c|c|c|c|c|c|c|c|c|c|c|c|c|}
\hline \multirow{2}{*}{$\begin{array}{c}\text { PARAMET } \\
\text { ERS }\end{array}$} & \multicolumn{4}{|c|}{ WEEK I } & \multicolumn{4}{|c|}{ WEEK 2} & \multicolumn{4}{|c|}{ WEEK 3} \\
\hline & 1A & 1B & 1C & 1D & $2 A$ & $2 B$ & 2C & 2D & $3 A$ & 3B & $3 C$ & 3D \\
\hline $\begin{array}{l}\text { Cholesterol } \\
\text { (mmolL-1) }\end{array}$ & $0.11 \pm 0.01$ & $\begin{array}{c}0.43 \pm 0.7 \\
1\end{array}$ & $0.11 \pm 0.01$ & $0.18 \pm 0.05$ & $0.11 \pm 0.01$ & $\begin{array}{c}0.48 \pm 0.7 \\
1\end{array}$ & $0.12 \pm 0.01$ & $0.19 \pm 0.05$ & $0.11 \pm 0.01$ & $\begin{array}{c}0.44 \pm 0.7 \\
1\end{array}$ & $0.11 \pm 0.01$ & $0.20 \pm 0.05$ \\
\hline $\begin{array}{c}\mathrm{TP} \\
\left(\mathrm{mmolL}^{-1}\right)\end{array}$ & $4.28 \pm 0.06$ & $\begin{array}{c}4.30 \pm 0.0 \\
3\end{array}$ & $3.96 \pm 0.06$ & $5.06 \pm 0.13$ & $4.25 \pm 0.06$ & $\begin{array}{c}4.39 \pm 0.0 \\
3\end{array}$ & $3.97 \pm 0.06$ & $5.06 \pm 0.13$ & $4.28 \pm 0.06$ & $\begin{array}{c}4.33 \pm 0.0 \\
3\end{array}$ & $3.96 \pm 0.06$ & $6.06 \pm 0.13$ \\
\hline $\begin{array}{c}\text { HDL } \\
\left(\mathrm{mmolL}^{-1}\right)\end{array}$ & $\begin{array}{c}15.73 \pm 1.6 \\
5\end{array}$ & $\begin{array}{c}11.69 \pm 1 \\
86\end{array}$ & $\begin{array}{c}20.76 \pm 9.2 \\
2 \\
\end{array}$ & $\begin{array}{c}22.84 \pm 6.7 \\
5 \\
\end{array}$ & $\begin{array}{c}15.79 \pm 1.6 \\
5\end{array}$ & $\begin{array}{c}11.70 \pm 1 \\
86\end{array}$ & $\begin{array}{c}20.78 \pm 9.2 \\
2 \\
\end{array}$ & $\begin{array}{c}22.89 \pm 6.7 \\
5\end{array}$ & $\begin{array}{c}15.73 \pm 1.6 \\
5\end{array}$ & $\begin{array}{c}11.69 \pm 1 \\
86\end{array}$ & $\begin{array}{c}21.76 \pm 9.2 \\
2\end{array}$ & $\begin{array}{c}23.84 \pm 6.7 \\
5 \\
\end{array}$ \\
\hline $\begin{array}{c}\text { LDL } \\
\left(\mathrm{mmolL}^{-1}\right)\end{array}$ & $0.90 \pm 0.26$ & $\begin{array}{c}0.06 \pm 0.0 \\
2^{* *}\end{array}$ & $0.89 \pm 0.14$ & $1.28 \pm 6.75$ & $0.90 \pm 0.26$ & $\begin{array}{c}0.07 \pm 0.0 \\
2^{* *}\end{array}$ & $0.90 \pm 0.14$ & $1.29 \pm 6.75$ & $0.90 \pm 0.26$ & $\begin{array}{c}0.06 \pm 0.0 \\
2^{* *}\end{array}$ & $0.89 \pm 0.14$ & $1.29 \pm 6.75$ \\
\hline TAG & $2.17 \pm 0.20$ & $1.15 \pm 0.4$ & $1.91 \pm 0.29$ & $2.02 \pm 0.08$ & $2.17 \pm 0.20$ & $1.15 \pm 0.4$ & $1.91 \pm 0.29$ & $2.02 \pm 0.08$ & $2.17 \pm 0.20$ & $1.15 \pm 0.4$ & $1.91 \pm 0.29$ & $2.07 \pm 0.08$ \\
\hline
\end{tabular}


Open Access Journal of Pharmaceutical Research

\begin{tabular}{|c|c|c|c|c|c|c|c|c|c|c|c|c|}
\hline$\left(\mathrm{mmolL}^{-1}\right)$ & & 5 & & & & 5 & & & & 5 & & \\
\hline $\operatorname{ALB}\left(\mathrm{gL}^{-1}\right)$ & $3.50 \pm 1.63$ & $\begin{array}{c}1.09 \pm 0.3 \\
4^{*}\end{array}$ & $3.90 \pm 1.58$ & $5.31 \pm 0.74$ & $3.50 \pm 1.63$ & $\begin{array}{c}1.09 \pm 0.3 \\
4^{*} \\
\end{array}$ & $3.90 \pm 1.58$ & $5.31 \pm 0.74$ & $3.50 \pm 1.63$ & $\begin{array}{c}1.09 \pm 0.3 \\
4^{*}\end{array}$ & $3.90 \pm 1.58$ & $5.34 \pm 0.74$ \\
\hline $\begin{array}{c}\text { AST } \\
\left(\mu \mathrm{molL}^{-1}\right)\end{array}$ & $\begin{array}{c}301.68 \pm 12 \\
.92\end{array}$ & $\begin{array}{c}328.35 \pm 9 \\
.62\end{array}$ & $\begin{array}{c}294.88 \pm 17 \\
.07\end{array}$ & $\begin{array}{c}373.42 \pm 47 \\
.45\end{array}$ & $\begin{array}{c}304.68 \pm 12 \\
.92\end{array}$ & $\begin{array}{c}329.35 \pm 9 \\
.62\end{array}$ & $\begin{array}{c}294.88 \pm 17 \\
.07\end{array}$ & $\begin{array}{c}374.42 \pm 47 \\
.45\end{array}$ & $\begin{array}{c}301.68 \pm 12 \\
.92\end{array}$ & $\begin{array}{c}328.35 \pm 9 \\
.62\end{array}$ & $\begin{array}{c}294.88 \pm 17 \\
.07\end{array}$ & $\begin{array}{c}373.52 \pm 47 \\
.45\end{array}$ \\
\hline$\underset{-1)}{\operatorname{ALT}(\mu \operatorname{molL}}$ & $\begin{array}{c}157.30 \pm 3 \\
17\end{array}$ & $\begin{array}{c}151.82 \pm 2 \\
.96\end{array}$ & $\begin{array}{c}154.15 \pm 6 \\
31\end{array}$ & $\begin{array}{c}170.76 \pm 9 . \\
66\end{array}$ & $\begin{array}{c}157.30 \pm 3 \\
17\end{array}$ & $\begin{array}{c}153.82 \pm 2 \\
.96\end{array}$ & $\begin{array}{c}155.15 \pm 6 \\
31\end{array}$ & $\begin{array}{c}172.76 \pm 9 \\
66\end{array}$ & $\begin{array}{c}157.30 \pm 3 \\
17\end{array}$ & $\begin{array}{c}151.82 \pm 2 \\
.96\end{array}$ & $\begin{array}{c}154.15 \pm 6 . \\
31\end{array}$ & $\begin{array}{c}170.76 \pm 9 . \\
66\end{array}$ \\
\hline $\begin{array}{c}\mathrm{ALP}(\mu \mathrm{molL} \\
-1)\end{array}$ & $\begin{array}{c}27.14 \pm 0.5 \\
5 \\
\end{array}$ & $\begin{array}{c}28.10 \pm 0 . \\
54\end{array}$ & $\begin{array}{c}27.70 \pm 0.3 \\
6 \\
\end{array}$ & $\begin{array}{c}77.05 \pm 27 \\
1 \\
\end{array}$ & $\begin{array}{c}27.14 \pm 0.5 \\
5 \\
\end{array}$ & $\begin{array}{c}28.10 \pm 0 . \\
54\end{array}$ & $\begin{array}{c}27.70 \pm 0.3 \\
6 \\
\end{array}$ & $\begin{array}{c}77.05 \pm 27 \\
1 \\
\end{array}$ & $\begin{array}{c}27.14 \pm 0.5 \\
5 \\
\end{array}$ & $\begin{array}{c}28.10 \pm 0 . \\
54\end{array}$ & $\begin{array}{c}27.70 \pm 0.3 \\
6 \\
\end{array}$ & $\begin{array}{c}78.05 \pm 27 \\
1 \\
\end{array}$ \\
\hline
\end{tabular}

Table 5A: Liver Biochemical Parameters of Rats Treated with Stem Bark Extracts of Spondias mombin(200 mg/kg).

Table 5a- Mean \pm SEM. *significantly different from control at $\mathrm{p}<0.05$,

$* *$ significantly different from control, B \& D at $\mathrm{p}<0.05$

\begin{tabular}{|c|c|c|c|c|c|c|c|c|c|c|c|c|}
\hline \multirow[b]{2}{*}{ Parameters } & \multirow[b]{2}{*}{$\mathbf{1 A}$} & \multicolumn{2}{|c|}{ WEEK I } & \multirow[b]{2}{*}{ 1D } & \multicolumn{3}{|c|}{ WEEK 2} & \multirow[b]{2}{*}{ 2D } & \multirow[b]{2}{*}{$3 \mathbf{A}$} & \multicolumn{2}{|c|}{ WEEK 3} & \multirow[b]{2}{*}{ 3D } \\
\hline & & $1 B$ & 1C & & $2 A$ & 2B & 2C & & & 3B & $3 \mathrm{C}$ & \\
\hline Cholesterol & $0.22 \pm 0.01$ & $0.39 \pm 0.71$ & $0.21 \pm 0.01$ & $0.18 \pm 0.05$ & $0.18 \pm 0.01$ & $0.48 \pm 0.71$ & $0.20 \pm 0.01$ & $0.19 \pm 0.05$ & $0.15 \pm 0.01$ & $0.45 \pm 0.71$ & $0.16 \pm 0.01$ & $0.20 \pm 0.05$ \\
\hline $\mathrm{TP}\left(\mathrm{mmolL}^{-1}\right)$ & $7.28 \pm 0.06$ & $8.30 \pm 0.03$ & $6.96 \pm 0.06$ & $5.06 \pm 0.13$ & $9.45 \pm 0.06$ & $7.39 \pm 0.03$ & $7.90 \pm 0.06$ & $5.06 \pm 0.13$ & $6.22 \pm 0.06$ & $6.33 \pm 0.03$ & $7.96 \pm 0.06$ & $6.06 \pm 0.13$ \\
\hline HDL $\left(\mathrm{mmolL}^{-1}\right)$ & $25.73 \pm 1.65$ & $21.69 \pm 1.86$ & $28.76 \pm 9.22$ & $22.84 \pm 6.75$ & $20.79 \pm 1.65$ & $25.70 \pm 1.86$ & $30.78 \pm 9.22$ & $22.89 \pm 6.75$ & $15.73 \pm 1.65$ & $18.49 \pm 1.86$ & $25.76 \pm 9.22$ & $23.84 \pm 6.75$ \\
\hline LDL (mmolL-1) & $0.98 \pm 0.26$ & $0.09 \pm 0.02 * *$ & $0.09 \pm 0.14$ & $1.28 \pm 6.75$ & $0.92 \pm 0.26$ & $0.09 \pm 0.02^{* *}$ & $1.90 \pm 0.14$ & $1.29 \pm 6.75$ & $0.91 \pm 0.26$ & $0.05 \pm 0.02 * *$ & $1.89 \pm 0.14$ & $1.29 \pm 6.75$ \\
\hline TAG $\left(\mathrm{mmolL}^{-1}\right)$ & $4.17 \pm 0.20$ & $3.15 \pm 0.45$ & $1.91 \pm 0.29$ & $2.02 \pm 0.08$ & $2.17 \pm 0.20$ & $3.15 \pm 0.50$ & $1.91 \pm 0.29$ & $2.02 \pm 0.08$ & $3.17 \pm 0.20$ & $2.15 \pm 0.21$ & $1.91 \pm 0.30$ & $2.07 \pm 0.08$ \\
\hline $\operatorname{ALB}\left(\mathrm{gL}^{-1}\right)$ & $6.50 \pm 1.63$ & $3.09 \pm 0.34^{*}$ & $3.90 \pm 1.58$ & $5.31 \pm 0.74$ & $4.50 \pm 1.63$ & $2.09 \pm 0.40^{*}$ & $2.90 \pm 1.58$ & $5.31 \pm 0.74$ & $3.50 \pm 1.63$ & $1.09 \pm 0.34^{*}$ & $3.90 \pm 1.58$ & $5.34 \pm 0.74$ \\
\hline $\operatorname{AST}\left(\mu \mathrm{molL}^{-1}\right)$ & $401.68 \pm 12.92$ & $2400.35 \pm 9.62$ & $394.88 \pm 17.07$ & $373.42 \pm 47.45$ & $504.68 \pm 12.9$ & $2398.35 \pm 9.62$ & $494.88 \pm 17.07$ & $374.42 \pm 47.45$ & $201.68 \pm 12.92$ & $328.35 \pm 9.62$ & $200.88 \pm 11.07$ & $373.52 \pm 47.45$ \\
\hline
\end{tabular}


Open Access Journal of Pharmaceutical Research

\begin{tabular}{|c|c|c|c|c|c|c|c|c|c|c|c|c|}
\hline ALT $\left(\mu \mathrm{molL}^{-1}\right)$ & $100.30 \pm 4.17$ & $251.82 \pm 2.96$ & $154.15 \pm 6.31$ & $170.76 \pm 9.66$ & $157.30 \pm 3.17$ & $253.82 \pm 2.96$ & $155.15 \pm 6.31$ & $172.76 \pm 9.66$ & $157.30 \pm 3.17$ & $151.82 \pm 2.96$ & $154.15 \pm 6.31$ & $170.76 \pm 9.66$ \\
\hline \multirow[t]{2}{*}{$\operatorname{ALP}\left(\mu \mathrm{molL}^{-1}\right)$} & $37.14 \pm$ & \multirow[t]{2}{*}{$30.10 \pm 0.54$} & \multirow[t]{2}{*}{$30.70 \pm 0.36$} & \multirow[t]{2}{*}{$77.05 \pm 27.1$} & \multirow[t]{2}{*}{$28.14 \pm 0.55$} & \multirow[t]{2}{*}{$28.10 \pm 0.54$} & \multirow[t]{2}{*}{$32.70 \pm 0.36$} & \multirow[t]{2}{*}{$77.05 \pm 27.1$} & \multirow[t]{2}{*}{$29.14 \pm 0.55$} & \multirow[t]{2}{*}{$25.10 \pm 0.54$} & \multirow[t]{2}{*}{$28.70 \pm 0.36$} & \multirow{2}{*}{$78.05 \pm 27.1$} \\
\hline & 0.55 & & & & & & & & & & & \\
\hline
\end{tabular}

Table 5B: Liver Biochemical Parameters of Rats Treated with Stem Bark Extracts of Spondias mombin (500 mg $/ \mathrm{kg}$ ).

Table 5b-Mean \pm SEM. * significantly different from control at $\mathrm{p}<0.05$,

${ }^{* *}$ significantly different from control, B \& D at $\mathrm{p}<0.05$

Key:

TP - Total protein TAG- triacylglyceride

ALT - Alanine amino transferase ALB- Alkaline Albumin

ALP - Alkaline phosphatase LDL - low-density lipoprotein

AST - Aspartate transaminase HDL- high-density lipoprotein,

\begin{tabular}{|c|c|c|c|c|c|c|c|c|c|c|c|c|}
\hline \multirow{2}{*}{ Parameters } & \multicolumn{4}{|c|}{ WEEK I } & \multicolumn{4}{|c|}{ WEEK 2} & \multicolumn{4}{|c|}{ WEEK 3} \\
\hline & $1 \mathrm{~A}$ & 1B & 1C & 1D & $2 \mathrm{~A}$ & 2B & $2 \mathrm{C}$ & 2D & $3 \mathbf{A}$ & 3B & $3 \mathrm{C}$ & 3D \\
\hline $\begin{array}{l}\text { Cholesterol } \\
\left(\text { mmolL-1) }^{-1}\right.\end{array}$ & $40.96 \pm 4.38$ & $73.82 \pm 4.39$ & $57.20 \pm 2.45$ & $66.08 \pm 4.98$ & $60.96 \pm 4.38$ & $58.82 \pm 4.39$ & $58.20 \pm 2.45$ & $66.10 \pm 4.98$ & $50.96 \pm 4.38$ & $73.82 \pm 4.39$ & $57.20 \pm 2.45$ & $67.08 \pm 4.98$ \\
\hline $\begin{array}{c}\text { TAG (mmolL- } \\
1 \text { ) }\end{array}$ & $54.26 \pm 0.07$ & $51.60 \pm 0.10$ & $53.00 \pm 0.09$ & $58.60 \pm 0.10$ & $55.26 \pm 0.07$ & $51.70 \pm 0.10$ & $53.05 \pm 0.09$ & $58.69 \pm 0.10$ & $54.26 \pm 0.07$ & $51.60 \pm 0.10$ & $54.00 \pm 0.09$ & $58.60 \pm 0.10$ \\
\hline $\begin{array}{c}\text { HDL (mmolL- } \\
1 \text { ) }\end{array}$ & $38.61 \pm 5.23$ & $54.21 \pm 4.55$ & $47.56 \pm 5.30$ & $45.37 \pm 5.80$ & $40.61 \pm 5.23$ & $40.31 \pm 4.55$ & $47.56 \pm 5.30$ & $45.47 \pm 5.80$ & $84.61 \pm 5.23$ & $54.21 \pm 4.55$ & $48.56 \pm 5.30$ & $45.47 \pm 5.80$ \\
\hline DL (mmolL-1) & $11.48 \pm 1.03$ & $08.22 \pm 0.14^{* *}$ & $12.86 \pm 1.16$ & $16.34 \pm 2.58$ & $11.42 \pm 1.03$ & $08.22 \pm 0.14^{* *}$ & $12.87 \pm 1.16$ & $16.54 \pm 2.58$ & $11.48 \pm 1.03$ & $09.22 \pm 0.14^{* *}$ & $12.86 \pm 1.16$ & $17.34 \pm 2.58$ \\
\hline TP (mmolL-1) & $49.16 \pm 0.19$ & $45.44 \pm 0.29$ & $50.58 \pm 0.13$ & $54.36 \pm 0.45$ & $49.17 \pm 0.19$ & $45.45 \pm 0.29$ & $50.58 \pm 0.13$ & $54.96 \pm 0.45$ & $49.16 \pm 0.19$ & $45.44 \pm 0.29$ & $51.58 \pm 0.13$ & $54.46 \pm 0.45$ \\
\hline ALB (gL-1) & $30.47 \pm 1.10$ & $44.00 \pm 1.61$ & $40.09 \pm 1.71$ & $38.41 \pm 1.22$ & $36.47 \pm 1.10$ & $34.05 \pm 1.61$ & $40.09 \pm 1.71$ & $38.51 \pm 1.22$ & $37.47 \pm 1.10$ & $44.00 \pm 1.61$ & $40.09 \pm 1.71$ & $39.41 \pm 1.22$ \\
\hline
\end{tabular}




\section{Open Access Journal of Pharmaceutical Research}

\begin{tabular}{|c|c|c|c|c|c|c|c|c|c|c|c|c|}
\hline AST $(\mu \mathrm{molL}-1)$ & $449.70 \pm 7.42$ & $2475.88 \pm 3.09$ & $9 \begin{array}{c}466.57 \pm 10.1 \\
4\end{array}$ & $\begin{array}{c}503.25 \pm 16.5 \\
2\end{array}$ & $429.70 \pm 7.42$ & $475.98 \pm 3.09$ & $\begin{array}{c}466.67 \pm 10.1 \\
4\end{array}$ & $\begin{array}{c}504.25 \pm 16.5 \\
2\end{array}$ & $449.70 \pm 7.42$ & $475.88 \pm 3.09$ & $466.57 \pm 10.14$ & $505.25 \pm 16.52$ \\
\hline ALT $(\mu \mathrm{molL}-1)$ & $126.10 \pm 1.26$ & $6127.12 \pm 6.12$ & $2120.85 \pm 3.68$ & $8132.85 \pm 3.83$ & $126.10 \pm 1.26$ & $127.17 \pm 6.12$ & $130.85 \pm 3.68$ & $132.86 \pm 3.83$ & $3126.10 \pm 1.26$ & $128.12 \pm 6.12$ & $120.85 \pm 3.68$ & $132.85 \pm 3.83$ \\
\hline ALP $(\mu \mathrm{molL}-1)$ & $20.13 \pm 7.34$ & $35.53 \pm 1.61$ & $37.17 \pm 20.70$ & $24.25 \pm 9.09$ & $20.13 \pm 7.34$ & $35.43 \pm 1.61$ & $37.17 \pm 20.70$ & $24.50 \pm 9.09$ & $31.13 \pm 7.34$ & $35.54 \pm 1.61$ & $37.17 \pm 20.70$ & $24.25 \pm 9.09$ \\
\hline $\begin{array}{c}\text { Sodium } \\
(\mathrm{mmolL}-1)\end{array}$ & $66.24 \pm 2.72$ & $69.66 \pm 3.72$ & $\begin{array}{c}114.69 \pm 20.5 \\
3\end{array}$ & $\begin{array}{c}107.71 \pm 10.0 \\
5\end{array}$ & $66.34 \pm 2.72$ & $69.66 \pm 3.72$ & $\begin{array}{c}114.69 \pm 20.5 \\
3\end{array}$ & $\begin{array}{c}107.82 \pm 10.0 \\
5\end{array}$ & $66.24 \pm 2.72$ & $69.66 \pm 3.72$ & $114.69 \pm 20.53$ & $108.71 \pm 10.05$ \\
\hline $\begin{array}{l}\text { Potassium } \\
\text { (mmolL-1) }\end{array}$ & $15.19 \pm 2.43$ & $9.83 \pm 1.67$ & $21.76 \pm 4.13$ & $21.52 \pm 3.05$ & $15.19 \pm 2.43$ & $9.83 \pm 1.67$ & $21.76 \pm 4.13$ & $21.52 \pm 3.05$ & $15.19 \pm 2.43$ & $9.83 \pm 1.67$ & $21.76 \pm 4.13$ & $22.52 \pm 3.05$ \\
\hline $\begin{array}{l}\text { Chloride } \\
\left(\text { mmolL-1) }^{-1}\right.\end{array}$ & $\begin{array}{c}169.96 \pm 10.3 \\
1\end{array}$ & $\begin{array}{c}179.25 \pm 22.7 \\
3\end{array}$ & $746.51 \pm 2.16$ & $6156.53 \pm 7.85$ & $149.96 \pm 10.3$ & $150.25 \pm 22.73$ & $146.21 \pm 2.16$ & $157.53 \pm 7.85$ & {$\left[\begin{array}{c}169.96 \pm 10.3 \\
1\end{array}\right.$} & $179.25 \pm 22.73$ & $146.51 \pm 2.16$ & $156.53 \pm 7.85$ \\
\hline $\begin{array}{l}\text { Bicarbonate } \\
\text { (mmolL-1) }\end{array}$ & $25.02 \pm 0.94$ & $22.85 \pm 0.39$ & $26.34 \pm 0.82$ & $27.26 \pm 0.32$ & $25.02 \pm 0.94$ & $23.85 \pm 0.39$ & $26.34 \pm 0.82$ & $28.26 \pm 0.32$ & $25.02 \pm 0.94$ & $22.85 \pm 0.39$ & $26.34 \pm 0.82$ & $27.26 \pm 0.32$ \\
\hline $\begin{array}{c}\text { Urea (mmolL- } \\
1 \text { ) }\end{array}$ & $35.49 \pm 2.77$ & $32.31 \pm 2.46$ & $29.72 \pm 1.42$ & $32.08 \pm 0.93$ & $31.49 \pm 2.77$ & $32.31 \pm 2.46$ & $29.72 \pm 1.42$ & $32.08 \pm 0.93$ & $35.49 \pm 2.77$ & $32.31 \pm 2.46$ & $29.72 \pm 1.42$ & $32.08 \pm 0.93$ \\
\hline $\begin{array}{l}\text { Creatinine } \\
\text { (mmolL-1) }\end{array}$ & $21.68 \pm 0.44$ & $26.32 \pm 0.19$ & $29.16 \pm 0.59$ & $20.62 \pm 0.27$ & $19.78 \pm 0.44$ & $19.40 \pm 0.19$ & $29.16 \pm 0.59$ & $20.62 \pm 0.27$ & $21.68 \pm 0.44$ & $27.32 \pm 0.19$ & $29.16 \pm 0.59$ & $20.62 \pm 0.27$ \\
\hline
\end{tabular}

Table 6A: Serum Biochemical Parameters of Rats Treated with Stem Bark Extracts of Spondias mombin (200 mg/kg). Mean \pm SEM. ${ }^{* *}$ significantly different from control at $\mathrm{p}<0$. 


\section{Open Access Journal of Pharmaceutical Research}

\begin{tabular}{|c|c|c|c|c|c|c|c|c|c|c|c|c|}
\hline \multirow[b]{2}{*}{ Parameters } & \multicolumn{4}{|c|}{ Week 1} & \multicolumn{4}{|c|}{ Week 2} & \multicolumn{4}{|c|}{ Week 3} \\
\hline & 1A & $1 \mathrm{~B}$ & 1C & 1D & $2 A$ & 2B & 2C & 2D & $3 A$ & 3B & $3 \mathrm{C}$ & 3D \\
\hline $\begin{array}{c}\text { Cholesterol } \\
\left(\mathrm{mmolL}^{-1}\right)\end{array}$ & $49.56 \pm 4.38$ & $80.82 \pm 4.39$ & $60.20 \pm 2.45$ & $70.08 \pm 4.98$ & $65.96 \pm 4.38$ & $51.82 \pm 4.39$ & $80.20 \pm 2.55$ & $76.10 \pm 4.88$ & $60.96 \pm 4.40$ & $73.82 \pm 4.39$ & $57.20 \pm 2.45$ & $67.08 \pm 4.98$ \\
\hline $\begin{array}{c}\text { TAG } \\
(\mathrm{mmolL}-1)\end{array}$ & $60.26 \pm 0.07$ & $60.60 \pm 0.10$ & $57.00 \pm 0.07$ & $70.60 \pm 0.10$ & $65.26 \pm 0.08$ & $59.70 \pm 0.20$ & $51.05 \pm 0.09$ & $58.69 \pm 0.10$ & $52.26 \pm 0.07$ & $51.60 \pm 0.10$ & $54.00 \pm 0.09$ & $58.60 \pm 0.10$ \\
\hline $\begin{array}{c}\text { HDL } \\
\text { (mmolL-1) }\end{array}$ & $37.61 \pm 5.23$ & $58.21 \pm 4.55$ & $41.56 \pm 5.30$ & $40.37 \pm 5.80$ & $40.61 \pm 5.23$ & $40.31 \pm 4.55$ & $49.56 \pm 5.30$ & $45.47 \pm 5.80$ & $90.61 \pm 5.23$ & $54.21 \pm 4.55$ & $48.56 \pm 5.30$ & $45.47 \pm 5.80$ \\
\hline $\begin{array}{c}\text { LDL } \\
\text { (mmolL-1) }\end{array}$ & $14.48 \pm 1.03$ & $08.22 \pm 0.14^{*}$ & * $13.86 \pm 1.17$ & $17.34 \pm 2.58$ & $12.42 \pm 1.03$ & $09.22 \pm 0.15^{* *}$ & $14.87 \pm 1.16$ & $16.54 \pm 2.58$ & $12.50 \pm 1.03$ & $09.22 \pm 0.14^{* *}$ & $12.86 \pm 1.16$ & $17.34 \pm 2.58$ \\
\hline $\begin{array}{c}\mathrm{TP}(\mathrm{mmolL}- \\
1)\end{array}$ & $50.16 \pm 0.19$ & $45.44 \pm 0.29$ & $50.58 \pm 0.13$ & $65.36 \pm 0.45$ & $48.17 \pm 0.19$ & $40.45 \pm 0.29$ & $70.58 \pm 0.13$ & $64.96 \pm 0.60$ & $50.16 \pm 0.19$ & $45.44 \pm 0.29$ & $54.58 \pm 0.14$ & $54.46 \pm 0.45$ \\
\hline $\begin{array}{c}\text { ALB } \\
\text { (gL-1) }\end{array}$ & $40.47 \pm 1.20$ & $45.00 \pm 1.61$ & $41.09 \pm 1.71$ & $39.41 \pm 1.22$ & $37.47 \pm 1.20$ & $44.05 \pm 1.61$ & $43.09 \pm 1.71$ & $38.51 \pm 1.22$ & $37.47 \pm 1.10$ & $44.00 \pm 1.61$ & $40.09 \pm 1.71$ & $39.41 \pm 1.22$ \\
\hline $\begin{array}{c}\text { AST }(\mu \text { molL- } \\
1)\end{array}$ & $500.70 \pm 7.44$ & $470.88 \pm 3.19$ & $461.57 \pm 10.14$ & $603.25 \pm 16.52$ & $459.70 \pm 7.42$ & $575.98 \pm 3.09$ & $496.67 \pm 10.15$ & $506.25 \pm 16.52$ & $500.70 \pm 7.42$ & $475.88 \pm 3.09$ & $466.57 \pm 10.14$ & $5505.25 \pm 16.52$ \\
\hline $\begin{array}{c}\operatorname{ALT}(\mu \mathrm{molL}- \\
1)\end{array}$ & $129.10 \pm 1.26$ & $127.12 \pm 6.12$ & $128.85 \pm 3.68$ & $182.85 \pm 3.83$ & $146.10 \pm 1.26$ & $137.17 \pm 6.12$ & $139.85 \pm 3.68$ & $137.86 \pm 3.83$ & $126.10 \pm 1.26$ & $128.12 \pm 6.12$ & $120.85 \pm 3.68$ & $132.85 \pm 3.83$ \\
\hline $\begin{array}{c}\operatorname{ALP}(\mu \mathrm{molL}- \\
1)\end{array}$ & $30.13 \pm 7.34$ & $39.53 \pm 1.61$ & $37.17 \pm 20.70$ & $34.25 \pm 9.09$ & $28.13 \pm 7.34$ & $35.43 \pm 1.70$ & $47.17 \pm 20.70$ & $24.50 \pm 9.09$ & $30.13 \pm 7.34$ & $35.54 \pm 1.61$ & $37.17 \pm 20.70$ & $24.25 \pm 9.09$ \\
\hline $\begin{array}{c}\text { Sodium } \\
\text { (mmolL-1) }\end{array}$ & $65.24 \pm 2.72$ & $68.66 \pm 3.72$ & $117.69 \pm 20.53$ & $117.71 \pm 10.05$ & $69.34 \pm 2.72$ & $70.66 \pm 3.72$ & $114.69 \pm 20.53$ & $3117.82 \pm 10.05$ & $67.24 \pm 2.72$ & $69.66 \pm 3.72$ & $114.69 \pm 20.53$ & $3108.71 \pm 10.05$ \\
\hline $\begin{array}{l}\text { Potassium } \\
\text { (mmolL-1) }\end{array}$ & $17.19 \pm 2.43$ & $9.85 \pm 1.67$ & $26.76 \pm 4.13$ & $23.52 \pm 3.05$ & $17.19 \pm 2.43$ & $9.93 \pm 1.63$ & $25.76 \pm 4.13$ & $21.52 \pm 3.05$ & $19.19 \pm 2.43$ & $9.83 \pm 1.67$ & $21.76 \pm 4.13$ & $22.52 \pm 3.05$ \\
\hline
\end{tabular}


Open Access Journal of Pharmaceutical Research

\begin{tabular}{|c|c|c|c|c|c|c|c|c|c|c|c|c|}
\hline $\begin{array}{l}\text { Chloride } \\
\left(\text { mmolL-1) }^{-1}\right)\end{array}$ & $169.96 \pm 11.31$ & $179.25 \pm 24.73$ & $146.51 \pm 3.16$ & $156.53 \pm 7.95$ & $149.96 \pm 11.31$ & $150.25 \pm 23.73$ & $146.21 \pm 2.17$ & $157.53 \pm 7.95$ & $169.96 \pm 11.31$ & $1179.25 \pm 22.73$ & $3146.51 \pm 2.16$ & $156.53 \pm 7.85$ \\
\hline $\begin{array}{c}\text { Urea } \\
\left(\mathrm{mmolL}^{-1}\right)\end{array}$ & $38.49 \pm 2.77$ & $32.31 \pm 2.46$ & $30.72 \pm 1.42$ & $31.08 \pm 0.93$ & $33.49 \pm 2.77$ & $34.31 \pm 2.46$ & $30.72 \pm 1.42$ & $35.08 \pm 0.93$ & $39.49 \pm 2.77$ & $32.31 \pm 2.46$ & $29.72 \pm 1.42$ & $32.08 \pm 0.93$ \\
\hline $\begin{array}{l}\text { Creatinine } \\
\text { (mmolL-1) }\end{array}$ & $21.68 \pm 0.44$ & $26.32 \pm 0.19$ & $29.16 \pm 0.59$ & $20.62 \pm 0.27$ & $19.78 \pm 0.44$ & $19.40 \pm 0.19$ & $29.16 \pm 0.59$ & $20.62 \pm 0.27$ & $21.68 \pm 0.44$ & $27.32 \pm 0.19$ & $29.16 \pm 0.59$ & $20.62 \pm 0.27$ \\
\hline
\end{tabular}

Table 6B: Serum Biochemical Parameters of Rats Treated with Stem Bark Extracts of Spondias mombin(500 mg/kg).

Mean \pm SEM. ${ }^{* *}$ significantly different from control at $\mathrm{p}<0$.

KEY:

TP - Total protein TAG- triacylglyceride

ALT - Alanine amino transferase ALB- Alkaline Albumin

ALP - Alkaline phosphatase LDL - low-density lipoprotein

AST - Aspartate transaminase

HDL- high-density lipoprotein

$A=200 \mathrm{mg} / \mathrm{kg}$ and $500 \mathrm{mg} / \mathrm{kg}$ body weight doses of crude aqueous stem bark extract of Spondias mombin,

$\mathbf{B}=200 \mathrm{mg} / \mathrm{kg}$ and $500 \mathrm{mg} / \mathrm{kg}$ body weight doses of crude ethanolicstem bark extract of Spondias mombin

C $=200 \mathrm{mg} / \mathrm{kg}$ and $500 \mathrm{mg} / \mathrm{kg}$ body weight doses of crude ethyl acetate stem bark extracts of Spondias mombin

$\mathrm{D}=$ Control 


\section{Open Access Journal of Pharmaceutical Research}

\section{Discussion}

The purpose of this study is to evaluate the in-vivo toxicity assessment of stem bark extracts of Spondias mombin on male and female albino rats. In table 2, the extracts of Spondias mombin stem bark increased water intake in the rats treated with 200 and $500 \mathrm{mg} / \mathrm{kg}^{-1}$ ethyl acetate and ethanolic extracts of Spondias mombin and this may be due to dehydration caused by increase water excretion by the kidney. The observed pronounced effect of Spondias mombin extract on the water intake of the albinorats in this study may be due to disruption in ant diuretic hormone secretion in the hypothalamus or due to disruption in the normal functioning of the kidney [2426].

Toxicological studies show that the Spondias mombin extracts were not toxic in the first week of administration but showed varying effects in the second and third weeks of treatment. Jovanoic, et al. [27] reported that the no alteration observed in the liver and kidney, the observable features are dose and time dependent. The presence of nephritic necrosis is not unexpected since excretion is mainly carried out in the kidney; the observation found in the kidney of the extracts treated rats is in accordance with the finding in the study that reported that no tubular necrosis occurred in rats fed with anti-nutritive factors containing feeds [28].

It was observed that ethyl acetate and ethanolic stem bark extracts of Spondias mombin suppressed the body weight, food consumption at 200 and $500 \mathrm{mg} / \mathrm{kg}$ ${ }^{1}$ compared to control (Table 1). This implies that the appetite of the treated animal (male and female albino rats) was grossly affected. The extreme lateral part of the ventromedial nucleus of the hypothalamus is responsible for the food intake and it has been indicated that leptin acts on the hypothalamus to decrease food intake, and it has been stated that body weight is an indicator of drug effect and is used to assess the response to drug therapy Zhao, et al. [29]. It should be noted that the effect of aqueous, ethanolic and ethyl acetate extracts of Spondias mombin was significant $(\mathrm{P}<0.005)$ compared to the control. Consumption of food decreased in all groups at $2^{\text {nd }}$ and $3^{\text {rd }}$ weeks in ethanolic and ethyl acetate extracts but the decrease was significant $(P>0.05)$ in aqueous extracts when compared to control. A significant ( $\mathrm{P}>0.05$ ) increase as shown in table 2 and $3 a$, The intake of water in all treated group was recorded in the first two weeks of treatment, however, a significant decrease $(\mathrm{P}<0.05)$ was observed in all treated group during $2^{\text {nd }}$ and $3^{\text {rd }}$ week of administration of all extract of $S$. mombin. The observed effect of the food consumption and the body weight of treated animal may be a response to the effect of Spondias mombin extract mediated through the hypothalamus, it should be stated that Spondias mombin extract may be used to reduce body weight and unnecessary fat on the adipose tissue of human system, a good natural therapy to reduce obesity in both old young adult [30]. This is one of the observable feature in tables $1,2,3 \mathrm{a}$ and $3 \mathrm{~b}$.

Evaluation of haematological indices also revealed minimal effect by the extract, except for white blood cell (WBC) count which showed a dose-dependent (200-500 $\mathrm{mg} / \mathrm{kg}$ ) significant increment towards the control. At a low dose of $200 \mathrm{mg} / \mathrm{kg}$ body weight of the Spondias mombin, the extract showed a reduced count of WBC compared to the control. This is further increased at 200 $\mathrm{mg} / \mathrm{kg}$ and $500 \mathrm{mg} / \mathrm{kg}$ body weights of the Spondias extract. This suggests that the extract has a positive effect on WBC count at high doses. WBCs are immunological cells that help fight the invasion of foreign bodies and disease infections in the system. The extract increasing the WBC count at high doses suggests that Spondias extract may enhance the immune system by elevation of levels of WBCs as shown in table $4 \mathrm{a}$ and $4 \mathrm{~b}$,

In sub-acute studies, daily administration of different doses of stem bark extracts of Spondias mombin for 14 days in rats had minimal effect. There was no significant change in the levels of the serum biochemical parameters AST, ALT, and bilirubin in 200 and $500 \mathrm{mg} / \mathrm{kg}^{-1}$ ethyl acetate and ethanolic extracts of Spondias mombin with reduced activity in aqueous extracts compared to the control group, though there was slight decrease in GGT levels (with the exception of $500 \mathrm{mg} / \mathrm{kg}$. wt), synthesis of albumin was not least compromised in 200 and 500 $\mathrm{mg} / \mathrm{kg}^{-1}$ concentration confirming no effect of extract on the metabolic roles of the liver shown in table $5 \mathrm{a}$ and $5 b$, The significant changes in the activities of the plasma and liver Aspartate aminotransferase (AST), Alanine aminotransferase (ACT), Alkaline phosphatase (ALP), Glutamyl transferase (GGT) and Bilirubin levels are good indices for detecting liver damage [31]. This demonstrated in table $5 \mathrm{a}$ and $5 \mathrm{~b}$. It was observed that the liver and kidney parameter were not affected by extracts of Spondias mombin stem bark, this signifies that the extract is not toxic to the experimental rats in decreasing order of activity from aqueous, ethanolic and ethyl acetate extracts of Spondias mombin

The serum level of ALT and AST was not altered by stem bark extract of Spondias mombin. (Table 6a and 6b). Level of other biochemical parameters was not significantly altered suggesting that the extracts were not hepato-toxic, which may be due to the presence of 


\section{Open Access Journal of Pharmaceutical Research}

antioxidant in Spondias mombin [32]. The reduced LDL value recorded in the liver and serum of the treated rats is in agreement with Igwe, et al. [33] who reported that the level of LDL was significantly reduced in animal groups treated with $500 \mathrm{mg} / \mathrm{kg}-1$ of the extracts. The decreased level of LDC suggested that it has a hypolipides effect and this support several reports on its lipid lowering effects [32].

Further analysis revealed the presence of alkaloids, tannins and reducing sugars in the extract, therefore isapossibility that this phytochemicalat low doses has no effect on liver or kidney cells, this is reflected in the minor increment in Procalcitonin (PCT) levels which have been reported to bring about apoptosis infectious cells in human system [34], at a low dose of 200 and $500 \mathrm{mg} / \mathrm{kg}$ body weight. At the same dose level, the presence of phenols in minor quantities could trigger possible interactions between the tetrachloride and phenols when in low quantities. This interaction is explained to form a final product, salicylaldehyde, which is known to be a key precursor of a number of chelating agents. The formation of chelating agents could affect membranous structures, inhibiting effective absorption and pernetration of the test drug into cells [35].

The stem bark extracts of Spondias mombin has no effect on the hematological indices of the albino rats all through the 21-days of administration as there was no significant difference in the values of red blood cell (RBC), white blood cell (WBC), HB HCT, MCV, MCV, MCH, MCHC and PCT in the treated rats and control. Murray, et al. [36] also reported that albumin is the major protein of the plasma and is responsible for the transportation of the fatty acids and bilirubin through the blood stream to the liver, the synthesis of albumin is depressed in the variety of diseases, particularly those in the liver. However, Oladiji [37] reported that in the first - three $\left(1^{\text {st }}-3^{\text {rd }}\right)$ week of treatment with the stem bark extracts of Spondias mombin, there was decrease in the $\mathrm{PCV}, \mathrm{HB}, \mathrm{MCH}$ of the experimental animal studies.

In conclusion, administration of stem bark extracts of Spondias mombin does not have significant toxic effects on liver and kidney cellular functions as well as on the hematological indices of female albino rats [38]. Rather, it elicited a dose-dependent increase in serum protein and haemoglobin concentrations, reduction in serum bilirubin concentration, hence its uses must be study and encouraged

\section{References}

1. Conforti F, Sosa S, Marrelli M, Menichini F, Statti GA, et al. (2008) Invivo anti-inflammatory and in invitro antioxidant activities of Mediterranean dietary plants. J Ethnopharmacol 116(1): 144-151.

2. Babu NP, Pandikumar P, Ignacimuthu S (2009) Antiinflammatory activity of Albizialeb beck Benth, an ethnomedicinal plant, in acute and chronic animal models of inflammation. Journal of Ethnopharmacology 125(2): 356-360.

3. Sati SC, Joshi S (2011) Aspects of antifungal potential of ethnobotanicallyknown medicinal plants. Research Journal of Medicinal Plants 5(4): 377-391.

4. Gill AO, Holley RA (2006) Disruption of Escherichia coli, Listeria monocytogenes and Lacto bacillus sakei cellular membranes by plant oil aromatics. Int J Food Microbiol 108(1): 1-9.

5. Okwu DE (2001) Evalution of chemical composition of indigenous spices and flavouringagents. Global J Appl Sci 7(3): 455-459.

6. Aregheore EM, Singh E (2003) Seasonal variation of macro- and micro-mineral contents of someruminant browse species from five countries in the South Pacific Region. Tropical Agriculture 80(2): 69-73.

7. Ayoka AO, Akomolafe RO, Iwalewa EO, Akanma MA, Ukponmwan OE (2006) Sedative, epileptic and antipsychotic effects of Spondias mombin L (Anacardiaceae) inmice and rats. Journal of Ethnopharmacolology 103(2): 166-175.

8. Chaisson RE, Martinson NA (2008). Tuberculosis in Africa: Combating an HIV-driven crisis. N Engl Journal of Medicine 358(11): 1089-1092.

9. Fred-Jaiyesimi A, Abo k, Wilkins R (2009) $\alpha$-Amylase inhibitory effect of 3 -olean-12-en-3-yl (9 Z)hexadec-9-enoate isolated from Spondias mombin leaf. Food Chemistry 116(1): 285-288.

10. Gupta RS, Chaudhary R, Yadav RK, Verma SK, Dobhal MP (2005) Effect of Saponins of Albizia lebbeck (L.) Benth bark on the reproductive system of male albino rats. Journal of Ethnopharmacology 96(1-4): 31-36. 


\section{Open Access Journal of Pharmaceutical Research}

11. Igwe GOC, Onyeze VA, Onwuliri CG, Osuagwu, Ojiako AO (2010) Evaluation of the chemical compositions of the leaf of Spondias Mombinlinn from Nigeria. Australian Journal of Basic and Applied Sciences 4(5): 706-710.

12. Taylor LND, Ubos (2012) (Spondias mombin), URL: http://rainforest data base.com/plants/ ubos.html.

13. Olugbuyiro JO, Moody MT, Hamann (2013) Phytosterols from Spondias mombin Linn. With antimycobacterial activities. African Journal of Biomedical Research 16(1): 19-24.

14. Adepoju OT, Oyewole OE, (2008) Nutrient Composition and Acceptability Study of Forti fied Jams from Spondias Mombin (Hog Plum, Iyeye in Yoruba) Fruit Pulp. Nigerian Journal of Nutritional Science 29(02): 180-189.

15. Nworu CS, Akah PA, Okoli CO, Okoye TC (2007) Oxytocic activity of leaf extract of Spon diasmombin. Pharmaceutical Biology 45(5): 366-371.

16. Lorke (1983) A new approach to practical acute toxicity testing. Archive of Toxicology 54(4): 275-287.

17. Diallo A, Eklu-Gadegkeku K, Agbonon A, Aklikokou K, Creppy EE, et al. (2010) Acute and sub-chronic (28day) oral toxicity studies of hydroalcohol leaf extract of Ageratumconyzoides L (Asteraceae). Tropical Journal of Pharmaceutical Research 9(5): 463-467.

18. Salamon D (2017) Analysis of viral epigenotypes using bisulfite sequencing: A detailed protocol for the crucial bisulfite modification and PCR amplification steps. Methods Mol Biol 1532: 207-213.

19. Konate KA, Souza M, Lamidi JF, Djoba Siawaya FHE, Mendene J, et al. (2011) Biological and toxicological effects of aqueous Acetone Extract of Cienfuegosia digitata Cav. (Malvaceae) in Mice and Rats. Journal of Pharmacology and Toxicology 6: 149-157.

20. Alexander RR, Griffiths JM (1993) Basic Biochemical methods 2nd ed. John Willey and Sons Inc. Publications New York, pp: 186-189.

21. Dacie JV, Lewis SM Practical Haematology. $8^{\text {th }}$ (Edn.), Longman Group Ltd.

22. Friedewald WT, Levy RI, Fredrickson DS (1972) Estimation of the concentration of low density lipoprotein cholesterol in plasma, without use of the preparative ultra centrifuge. Clin Chem 18(6): 499502.

23. Tietz NW (1990) Clinical Guide to Laboratory Tests. $2^{\text {nd }}(E d n)$, W.B. Saunders Company, Philadelphia, PA, USA, pp: 554-556.

24. Nosiri CI, Anuka JA, Radindadi AH (2010) Endosulfan induced polydyspia in adult wistar rats. Internet J Pharmacol 9(1): 1531-2976.

25. Oshima Y, Namao K, Kamijou A, Matsuoka S, Nakano $M$, et al. (1995) Powerful hepatoprotective and hepatotoxic plant oligostilbenes, isolated from the Oriental medicinal plant Vitiscoignetiae (Vitaceae) Cellular and Molecular life sciences 51(1): 63-66.

26. Schuppan D, Jia JD, Brinkhaus B, Hahn EG (1999) Herbal products for liver diseases: a therapeutic challenge for the new millennium. Hepatology 30(4): 1099-1104.

27. Jovanoic R, Savic S, Veselina P, Kolgajic V, Desanka K (1991) Antinutritive factors in feeding of domestic animals. KrunvaJ 2: 25-31.

28. Iweala EEJ, Oludare FD (2011) Hypoglycaemic effect, biochemical and histological changes of Spondias mombin and Parinari polyandra Benth. Seeds ethanolic extracts in alloxa-induced diabetic rats. J Pharmacol Toxicol 6(2): 101-112.

29. Zhao H, Fan W, Dong J, Lu J, Chen J, et al. (2008) Evaluation of antioxidant activities and total phenolic contents of typical malting barley varieties. Food Chemistry 107: 296.

30. Uboh FE, Okon IE, Ekong MB (2010) Effect of aqueous extract of Psidiumguajava leaves on liver enzymes, histological integrity and haematological indices in rats. Gastro enterol Res 3(1): 32-38.

31. Boelsterli UA (2003) Idiosyncratic drug hepatotoxicity revisited: new insights from mechanistic toxicology. Toxicology Mechanisms and Methods 13(1): 3-20.

32. Calderon AI, Angerhofer CK, Pezzuto JM, Farnsworth NR, Foster R, et al. (2010) Forest plots as a tool to demonstrate the pharmaceutical potential of plants in a tropical forest of Panama. Econ Bot 54(3): 278-294.

33. Igwe CU, Ojiako OA, Nwaogu LA, Onyeze GOC (2008) Lipid lowering effect of aqueous leaf extract of 
Spondias mombinLinn. The Internet J Pharmacol 6(1): p10.

34. Kaneto H, Fujii J, Myint T, Miyazawa N, Islam KN, et al. (1996) Reducing sugars trigger oxidative modification and apoptosis in pancreatic beta-cells by provoking oxidative stress through the glycation reaction. Biochem J 320(3): 855-863.

35. Osuntokun OT (2018) Histo Pathological Evaluations of the Effect of Stem Bark Extract of Spondias mombin (Linn) on Organs of Albino Rats. International Journal of Advances in Medical Sciences 3(2): 09-18.
36. Murray J, Zhang B, Taylor SW, Oglesbee D, Fahy E, et al. (2003) The subunit composition of the human NADH dehydrogenase obtained by rapid one-step immunopurification. J Biol Chem 278(16): 1361913622.

37. Oladiji AT, Abodunrin TP, yakubu MT (2010) Toxicological evaluation of Tetracarpidium conophorum nut oil-based diet in rats. Food Chem Toxicol 48(3): 898-902.

38. Priya KS, Gnanamani A, Redhakrishnan N, Babu M (2002) Healing potential of Daturaalbo on burn wounds in albino rats. J Ethnopharmacol 83(3): 193199. 